\title{
Gas Hydrate Prospecting Using Well Cuttings and Mud-Gas Geochemistry from 35 Wells, North Slope, Alaska
}

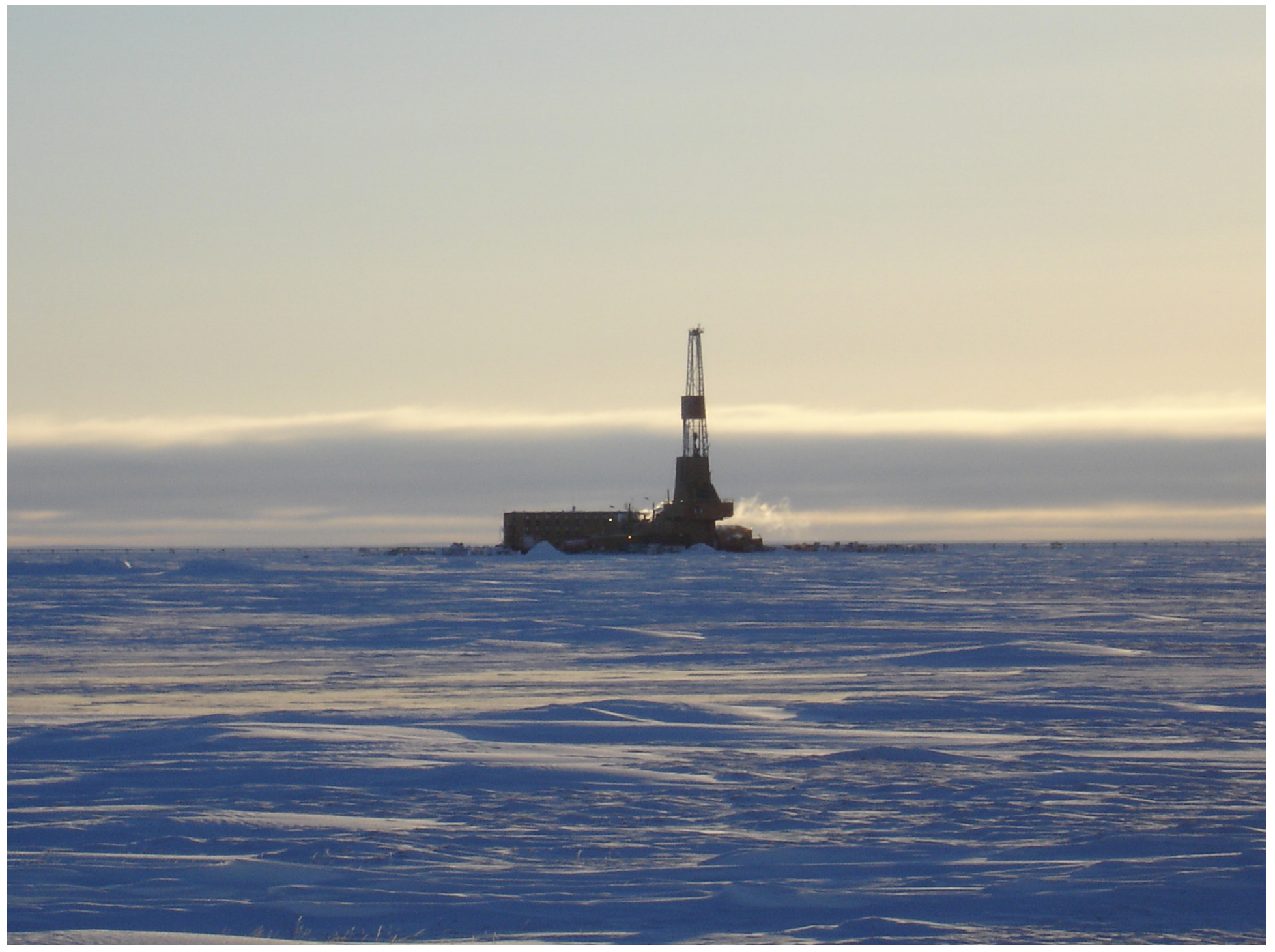

Scientific Investigations Report 2011-5195 
COVER. The Doyon 14 rig on an ice pad, drilling the Mount Elbert Gas Hydrate Stratigraphic Test Well, Alaska North Slope, February 2007. (Photograph by Ray Boswell.) 


\section{Gas Hydrate Prospecting Using Well Cuttings and Mud-Gas Geochemistry from 35 Wells, North Slope, Alaska}

By Thomas D. Lorenson and Timothy S. Collett

Scientific Investigations Report 2011-5195 


\section{U.S. Department of the Interior KEN SALAZAR, Secretary}

\section{U.S. Geological Survey Marcia K. McNutt, Director}

\section{U.S. Geological Survey, Reston, Virginia: 2011}

This report and any updates to it are available online at:

http://pubs.usgs.gov/sir/2011/5195/

For more information on the USGS - the Federal source for science about the Earth, its natural and living resources, natural hazards, and the environment:

World Wide Web: http://www.usgs.gov/

Telephone: 1-888-ASK-USGS

Any use of trade, product, or firm names in this publication is for descriptive purposes only and does not imply endorsement by the U.S. Government.

Although this report is in the public domain, it may contain copyrighted materials that are noted in the text. Permission to reproduce those items must be secured from the individual copyright owners.

Cataloging-in-Publication data are on file with the Library of Congress (URL http://www.loc.gov/).

Suggested citation: Lorenson, T.D., and Collett T.S., 2011, Gas hydrate prospecting using well cuttings and mud-gas geochemistry from 35 wells, North Slope, Alaska: U.S. Geological Survey Scientific Investigations Report 2011-5195, 27 p., available at http://pubs.usgs.gov/sir/2011/5195/. 


\section{Contents}

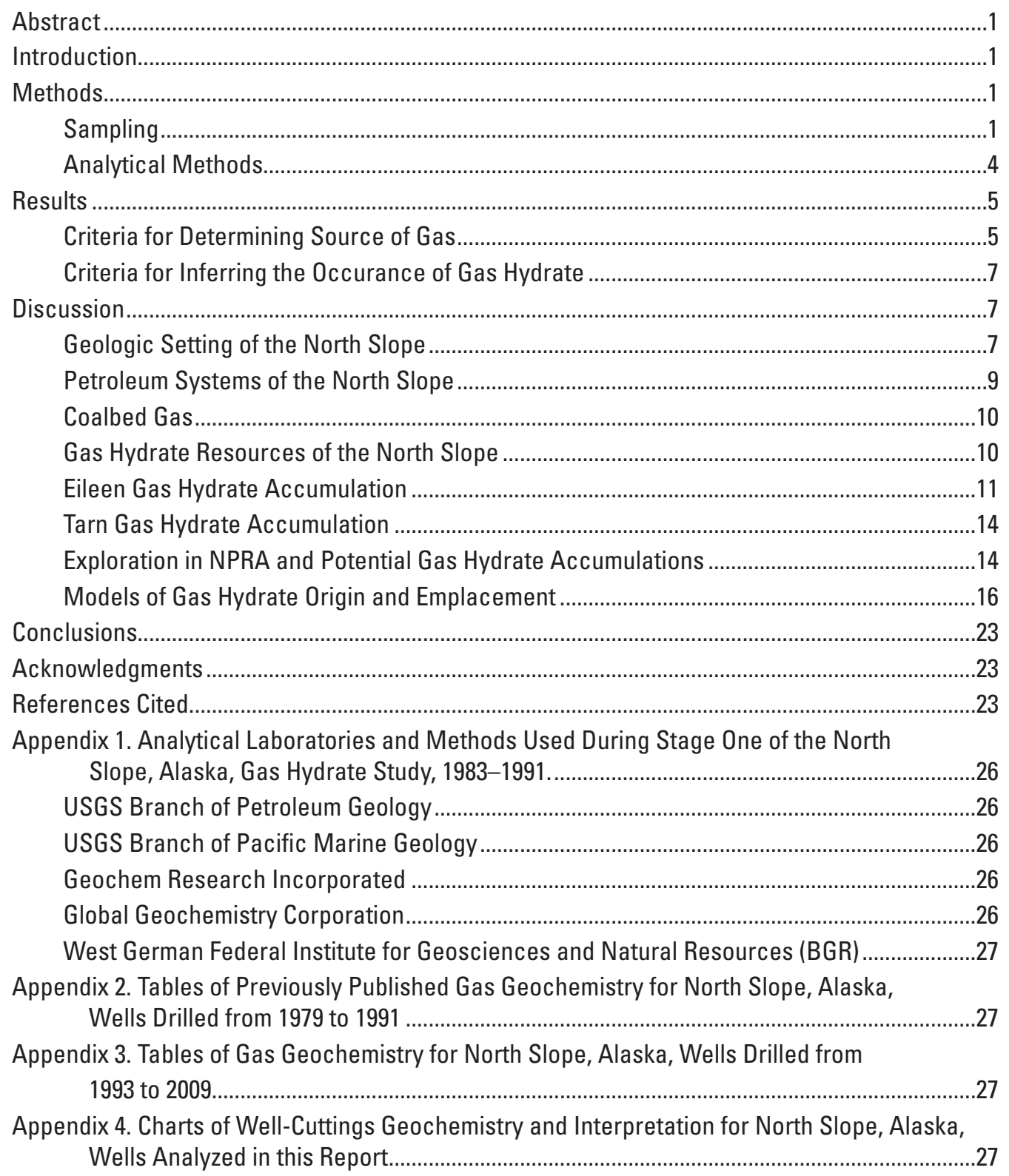

\section{Figures}

1. Map of the North Slope of Alaska showing locations of oil and gas wells analyzed

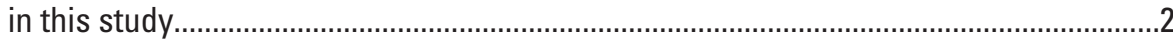

2. Generalized stratigraphic column for the of North Slope of Alaska................................8

3. Map of the North Slope of Alaska showing extent and location of the Brookian Coalbed Gas Composite Total Petroleum System (TPS), and areas within each assessment unit (AU) in the TPS that were assessed for coalbed-gas potential in Cretaceous and Tertiary rocks, North Slope and adjacent State waters, Alaska 
4. Area of potential gas hydrate occurrences in northern Alaska.....................................11

5. Partial map of the North Slope of Alaska $(A)$ showing the location of the cross section $(B)$, major petroleum fields in green, gas hydrate accumulations in blue, and free gas in red ..........................................................................................................

6. Geochemical data from the Mount Elbert 1 well ...............................................................13

7. Geochemical data from the Tarn $2 \mathrm{~N}-305$ well ......................................................................15

8. Map showing the potential occurrence of gas hydrate on the North Slope of Alaska

9. Detailed map showing the potential occurrence of gas hydrate on the North Slope of Alaska

10. Map showing evidence for thermogenic gas in wells on the North Slope of Alaska..... 19

11. Geochemical data from the Kokoda 5 well

12. Stylized cartoon showing a schematic cross section of the Prudhoe-Kuparuk area, showing possible gas sources, conduits, and traps, including the proposed filling history of the West Sak oil field (modified from Masterson and others, 2001)

13. Generalized proposed model for gas hydrate occurrences in the National Petroleum Reserve in Alaska (NPRA)

\section{Tables}

1. List of North Slope, Alaska, oil and gas wells sampled by the U.S. Geological Survey and Bureau of Land Management from 1983 to 2009 for gas geochemistry, including selected geothermal horizons (Collett and others; 2009), gas hydrate stability-zone thickness, and potential to intercept gas hydrate deposits

2. Projected and well-log picked gas hydrate intervals in selected North Slope, Alaska, oil and gas wells analyzed by the U.S. Geological Survey and Bureau of Land Management with well-logging tools 


\title{
Gas Hydrate Prospecting Using Well Cuttings and Mud- Gas Geochemistry from 35 Wells, North Slope, Alaska
}

\author{
By Thomas D. Lorenson and Timothy S. Collett
}

\section{Abstract}

Gas hydrate deposits are common on the North Slope of Alaska around Prudhoe Bay; however, the extent of these deposits is unknown outside of this area. As part of a U.S. Geological Survey (USGS) and Bureau of Land Management gas hydrate research collaboration, well-cutting and mud-gas samples have been collected and analyzed from mainly industry-drilled wells on the North Slope for the purpose of prospecting for gas hydrate deposits. On the Alaska North Slope, gas hydrates are now recognized as an element within a petroleum systems approach or "total petroleum system." Since 1979, 35 wells have been sampled from as far west as Wainwright to Prudhoe Bay in the east. Regionally, the USGS has assessed the gas hydrate resources of the North Slope and determined that there is about 85.4 trillion cubic feet of technically recoverable hydrate-bound gas within three assessment units. The assessment units are defined mainly by three separate stratigraphic sections and constrained by the physical temperatures and pressures where gas hydrate can form. Geochemical studies of known gas hydrate occurrences on the North Slope have shown a link between gas hydrate and more deeply buried conventional oil and gas deposits. The link is established when hydrocarbon gases migrate from depth and charge the reservoir rock within the gas hydrate stability zone. It is likely gases migrated into conventional traps as free gas and were later converted to gas hydrate in response to climate cooling concurrent with permafrost formation. Results from this study indicate that some thermogenic gas is present in 31 of the wells, with limited evidence of thermogenic gas in four other wells and only one well with no thermogenic gas. Gas hydrate is known to occur in one of the sampled wells, likely present in 22 others on the basis of gas geochemistry, and inferred by equivocal gas geochemistry in 11 wells, and one well was without gas hydrate. Gas migration routes are common in the North Slope and include faults and widespread, continuous shallowly dipping permeable sand sections that are potentially in communication with deeper oil and gas sources. The application of the petroleum system model with the geochemical evidence suggests that gas hydrate deposits may be widespread across the North Slope of Alaska.

\section{Introduction}

Large amounts of natural gas, composed mainly of methane, can occur in arctic sedimentary basins in the form of gas hydrates under appropriate temperature and pressure conditions. Northern Alaska is known to host several gas hydrate deposits that have been previously estimated to contain from 6.7 to 66.8 trillion cubic feet (TCF) of gas based on play analyses (Collett, 1997). In response to the need to assess the energy resource potential of gas hydrate in northern Alaska, the U.S. Geological Survey (USGS) and the Bureau of Land Management (BLM) have been collecting geochemical samples from mainly conventional petroleum industry development wells since 1979 for an ongoing research program in the Prudhoe Bay, Kuparuk River, and Milne Point fields in northern Alaska. In 2002, the sample collection was extended westward into the National Petroleum Reserve in Alaska (NPRA) (fig. 1). The results of this study are intended to aid in the geologic analysis of the occurrence of gas hydrates within northern Alaska to determine the role gas hydrate may play as a future domestic-energy resource.

\section{Methods}

\section{Sampling}

The following describes the sampling procedures used in obtaining samples for stage one of the USGS-BLM study, 1979-1991, described in Valin and Collett (1992). Drill cuttings and free-gas samples were obtained from 10 wells drilled in the Prudhoe Bay, Kuparuk River, and Milne Point oil fields (table 1, fig. 1). The drill cuttings were collected from the wells' shaker table and placed in either quart or pint-size metal cans. Water was added to submerge the cuttings, leaving about $1.5 \mathrm{~cm}$ of air-space or headspace at the top of the can. In most cases, a bactericide (zephiran chloride or sodium azide) was added to the water to prevent biological activity in the sample. The can was sealed with a metal lid. The free-gas samples were collected from the mud logger's gas trap, which is positioned within the mud pit at the back of the shaker table. The gas trap consists of a 15 -cm-diameter pipe sealed at one end and inverted over the shaker table. At the top of the gas trap is 

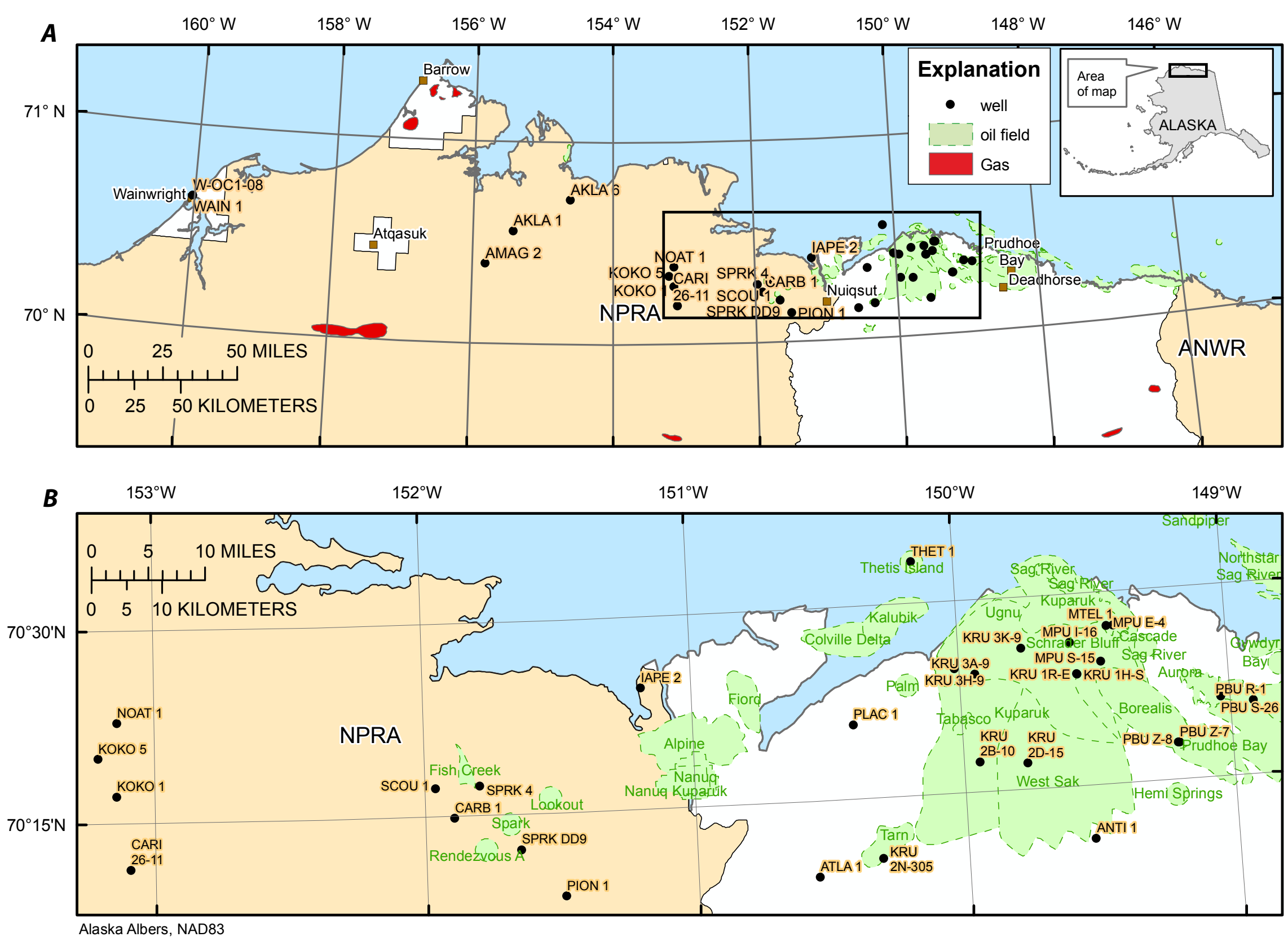

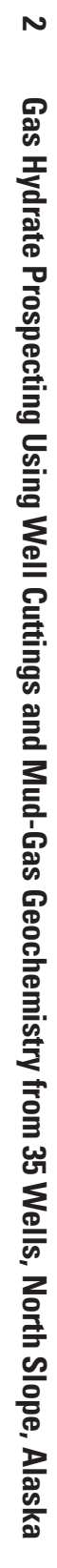

Figure 1. $A$, Map of the North Slope of Alaska showing locations of oil and gas wells analyzed in this study. See table 1 for explanation of well name abbreviations. $B$, Map showing detail within rectangle on A. NPRA, National Petroleum Reserve in Alaska; ANWR, Arctic National Wildlife Refuge. 
Table 1. List of North Slope, Alaska, oil and gas wells sampled by the U.S. Geological Survey and Bureau of Land Management from 1979 to 2009 for gas geochemistry, including selected geothermal horizons (Collett and others, 2009), gas hydrate stability-zone thickness, and potential to intercept gas hydrate deposits.

[API, American Petroleum Institute; GHSZ, gas hydrate stability zone; Co, company; AK, Alaska; DOI, U.S. Department of the Interior. Estimated depth horizons were calculated by the interpolation of geothermal horizon contours of Collett and others (2009). GHSZ thickness was calculated as the difference of the bottom GHSZ and top GHSZ. GHSZ 2 was calculated directly from interpolated contours of GHSZ thickness in Collett and others (2009).]

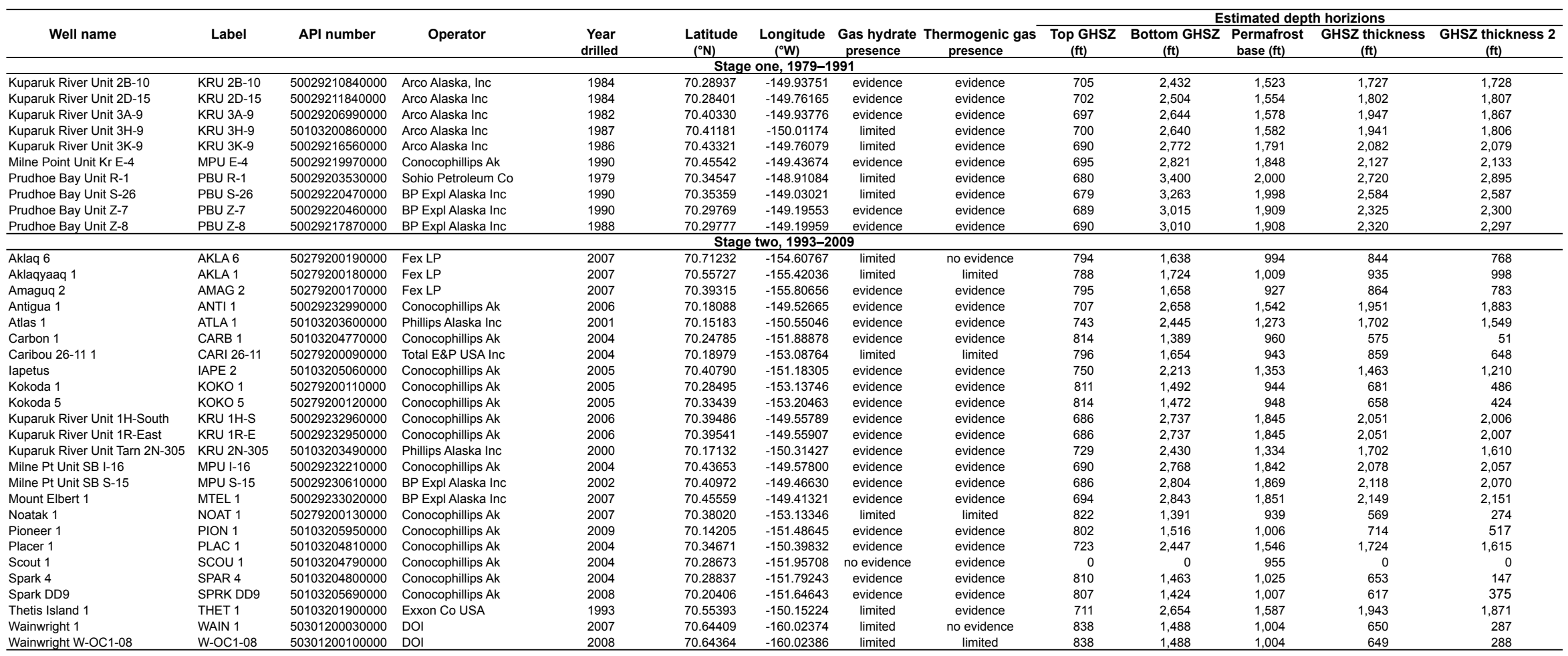


an agitator that separates the formation gas (mud gas in drilling parlance) from the drilling fluids. Both the shaker table and gas trap are open to the atmosphere. Most of the mud gas samples were collected in $400 \mathrm{~mL}$ glass bottles by a simple displacement method, performed by using a small vacuum pump to withdraw the gas sample from the mud logger's gas trap and inject the sample into a glass bottle that was filled with water and inverted in a water bath.

Similar sampling procedures were used to sample well cuttings and mud gas during stage two of the study (1993-2009). Minor differences and improvements were canning and freezing cuttings samples into smaller $500 \mathrm{~mL}$ metal cans without addition of water or bactericide and the sampling of mud gas from an in-line manifold leading to the mud loggers' analytical workspace. Cuttings gas samples were collected typically at 60 -ft intervals directly from the shaker table and stored frozen in septa-equipped cans until thawed and shaken for 5 minutes before analysis. Mud gas samples were stored in IsoTubes ${ }^{\mathrm{TM}}$ and sent directly to Isotech Geochemistry Laboratories for analysis.

\section{Analytical Methods}

The gas analyses of samples from stage one of the study were preformed by six different laboratories for the hydrocarbon gases methane to heptane and the carbon isotopes of methane, ethane, carbon dioxide, and the deuterium content of methane. Details of the laboratory analytical procedures are reproduced in appendix 1 or can be read in Valin and Collett (1992). Data tables taken from Valin and Collett (1992) are available in appendix 2. The terminology used in Valin and Collett (1992) refers to cuttings samples as "blended headspace analysis, BHA" and to mud gas samples as "headspace analysis, HS." The cuttings samples were not weighed, and the results cannot be quantified relative to the volume or mass of cuttings sampled, thus results are reported in parts per million (ppm) within tables in appendix 2 .

The analyses of samples from stage two were completed in three laboratories and are reported in tables in appendix 3. For wells drilled from 2000 to 2006, gas compositional analyses were determined at the laboratories of the USGS in Menlo Park, California. Here, a Shimadzu GC-14A gas chromatograph equipped with a Chemipack C-18, $6 \mathrm{ft} \times 1 / 8$ in., 80/100-mesh stainless steel column was used to measure hydrocarbon gases from methane up to isomers with seven carbon atoms. The GC$14 \mathrm{~A}$ is configured with a $1 \mathrm{~mL}$ valve-actuated sample loop for injection and a flame ionization detector (FID) for gas detection. Samples were introduced by syringe at atmospheric pressure, and a minimum of $10 \mathrm{~mL}$ of gas was used to flush the injection loop. Run conditions were $35^{\circ} \mathrm{C}$ for 1.5 minutes ramping up at $20^{\circ}$ /minute to $150^{\circ} \mathrm{C}$ and held. Helium was used as the carrier gas at a constant mass flow rate of $3 \mathrm{~kg} / \mathrm{cm}^{2}$. FID temperature was held at $150^{\circ} \mathrm{C}$.

Hydrocarbon gases were measured and reported (tables in appendix 3) relative to the volume of cuttings from which the gases were extracted, that is, microliters of gas per liter of cuttings $(\mu \mathrm{L} / \mathrm{L})$; methane $\left(\mathrm{C}_{1}\right)$, ethane $\left(\mathrm{C}_{2}\right)$, propane $\left(\mathrm{C}_{3}\right)$, isobutane $\left(i \mathrm{C}_{4}\right)$, normal butane $\left(n \mathrm{C}_{4}\right)$, neopentane $\left(\right.$ neo $\left._{5}\right)$, isopentane $\left(i \mathrm{C}_{5}\right)$, normal pentane $\left(n \mathrm{C}_{5}\right), 2$, 2 dimethylbutane (2-2DMB), 2 methylpentane (2MP), 3 methylpentane (3MP), normal hexane $\left(\mathrm{C}_{6}\right)$, and methylcyclohexane $(\mathrm{MCH})$. Approximate detection limits for all hydrocarbon compounds are 0.05 parts per million by volume (ppmv). $\mathrm{CO}_{2}$ measurements were made on a Hewlett Packard micro-GC equipped with an 8-m poraplot U column and detected by a thermal conductivity detector. The approximate detection limit for $\mathrm{CO}_{2}$ measurements is about 50 ppmv.

At the School of Earth and Ocean Sciences (SOES), University of Victoria, Canada, stable carbon isotope ratio determinations of $\mathrm{C}_{1}, \mathrm{C}_{2}, \mathrm{C}_{3}, i \mathrm{C}_{4}, n \mathrm{C}_{4}$, and $\mathrm{CO}_{2}$ were made on a continuous flow-isotope ratio mass spectrometer (Finnigan MAT 252 GC-C-IRMS). Wells drilled from 2000 to 2006 were analyzed here for stable carbon isotope composition. Samples are introduced by syringe into a SRI gas chromatograph (GC) via a gas sample valve (loop volumes: 10, 100, or $200 \mathrm{~mL}$ ). Analytes are separated at $40^{\circ} \mathrm{C}$ on a $30-\mathrm{m}$ GS-Q column $(0.32 \mathrm{~mm}$ ID) with a carrier gas flow of $1.8 \mathrm{~mL} / \mathrm{min}$ ultra-high purity helium. After gas partitioning on the $\mathrm{GC}$, the gas then passes through a $\mathrm{CuO} /$ Pt micro-combustion oven at $850^{\circ} \mathrm{C}$. This oven quantitatively converts the hydrocarbon gases to carbon dioxide and water. The combusted sample products are then passed through a Nafion ${ }^{\text {TM }}$ tube to remove water from the combustion, as well as any water that may be in the carrier gas. The purified $\mathrm{CO}_{2} / \mathrm{He}$ pulse is scaled by an open-split interface, then transferred into the GC-C-IRMS. Isotope ratios are referenced to the conventional PDB standard through a known $\mathrm{CO}_{2}$ isotope standard that is added at the open split to the sample runs several times during the analysis.

For stable carbon isotope ratio measurements on the $\mathrm{CO}_{2}$ sample, the gas was partitioned on the GC as above. The microcombustion oven was bypassed for the $\mathrm{CO}_{2}$ measurements, but the gas stream was dried, split, and measured by CF-IRMS in a manner similar to the light hydrocarbons.

The analysis of samples from wells drilled from 2007 to 2009 was completed by Isotech Laboratories, Champaign, Illinois, for gas compositional analyses and isotopic analyses of hydrocarbon gases and carbon dioxide. Compositional analyses of gas samples are measured on a custom-configured Shimadzu 2040 GC system. The system operates isothermally, utilizing valve switching and multiple columns to separate the various components found in natural gas samples. The major fixed gases and high concentration methane are quantified using a TCD detector, while low-concentration methane and other hydrocarbons down to about $1 \mathrm{ppm}$ are measured using an FID detector. Peak integration and quantification is accomplished using EZChrom software. Results are reported in tables within appendix 3 relative to the volume of cuttings or core material from which the gases were extracted, that is, microliters of gas per liter of cuttings $(\mu \mathrm{L} / \mathrm{L})$ for methane $\left(\mathrm{C}_{1}\right)$, ethane $\left(\mathrm{C}_{2}\right)$, ethylene $\left(\mathrm{C}_{2} \mathrm{H}_{4}\right)$, propane $\left(\mathrm{C}_{3}\right)$, propylene $\left(\mathrm{C}_{3} \mathrm{H}_{6}\right)$, isobutane $\left(i \mathrm{C}_{4}\right)$, normal butane $\left(n \mathrm{C}_{4}\right)$, isopentane $\left(i \mathrm{C}_{5}\right)$, normal pentane $\left(n \mathrm{C}_{5}\right)$, and normal hexanes and heptanes $\left(\mathrm{C}_{6+}\right)$. The analysis includes nonhydrocarbon gases; $\left(\mathrm{H}_{2}\right)$, hydrogen $\left(\mathrm{O}_{2}\right)$, oxygen $\left(\mathrm{N}_{2}\right)$, nitrogen $\left(\mathrm{CO}_{2}\right)$, carbon dioxide $(\mathrm{CO})$, carbon monoxide, helium 
(He), and (Ar) argon. Sample sets collected directly as gas (mud gas) are reported in parts per million by volume (ppm).

The carbon isotopic composition of hydrocarbons and $\mathrm{CO}_{2}$ for wells drilled from 2007 to 2009 was determined by Isotech Laboratories in Champaign, Illinois, using a GC-C-IRMS system, consisting of an Agilent $6890 \mathrm{GC}$ combustion unit and Finnegan GCCIII interfaced with a mass spectrometer (Delta V Plus or Delta Plus Advantage). The methane was separated by the GC column in the HP6890, then combusted in a combustion furnace. The resultant $\mathrm{CO}_{2}$ was introduced directly into the mass spectrometer. Hydrogen isotopic values for methane were completed using the same system, but the methane was channeled through a high-temperature pyrolysis furnace instead of through the combustion furnace. The pyrolysis furnace converted methane into $\mathrm{H}_{2}$ and carbon, and the $\mathrm{H}_{2}$ gas was introduced directly into the mass spectrometer. Reference gases were analyzed at the start of each analysis sequence, and at least 10 percent of all analyses during a sequence were check samples. Ten percent of the samples were analyzed in duplicate. The measured stable carbon isotope ratios are expressed in the delta notation, defined as parts per thousand (\%), relative to the standard of Vienna Peedee Belemnite (VPDB). The precision of the carbon isotope analysis was $\pm 0.5 \%$, based on $1 \mathrm{~s}$ standard deviation of measurements on the standard.

\section{Results}

An important qualification in our work is that the gas composition of the cuttings samples may not reflect exactly the in-situ gas composition of the stratigraphic interval that was sampled. The cuttings samples collected for the headspace analyses have undergone varying degrees of degassing before sealing in cans. Kvenvolden and Lorenson (2000) concluded that the headspace extraction technique is concentration dependent. For example, gases that are below saturation in situ can be realistically recovered; however, any gas concentration above saturation at surface conditions will exsolve during recovery and undergo varying degrees of degassing fractionation when exposed at surface conditions (Faber and Stahl, 1983; Berner and Bertrand, 1991). Methane is the most common and concentrated hydrocarbon gas in sediments and is preferentially lost relative to other hydrocarbon gases during the sampling process, resulting in a reduction of the often-used diagnostic methane to ethane plus propane $\left(\mathrm{C}_{1} / \mathrm{C}_{2}+\mathrm{C}_{3}\right)$ ratio for any sample exposed to the atmosphere. The cuttings gas samples are more prone to loss of methane relative to the mud gas samples resulting in lower $\mathrm{C}_{1} / \mathrm{C}_{2}+\mathrm{C}_{3}$ ratios versus those of mud gas samples from the same depth intervals. Longer exposure times of cuttings versus mud gas to atmospheric conditions before sampling results in more preferential loss of methane and a further reduction of the $\mathrm{C}_{1} /$ $\mathrm{C}_{2}+\mathrm{C}_{3}$ ratio.

The degassing process also results in preferential loss of ${ }^{12} \mathrm{C}$-enriched methane, with the degree of degassing dependent on the properties of the sediment. Coarse-grained, unlithified sediments undergo greater gas loss than finer-grained, more lithified rocks. Thus, the cuttings have undergone some degassing before analyses and reported $(\mu \mathrm{L} / \mathrm{L}$ sediment) concentrations are minimum values. Gas concentrations and isotopic compositions for all samples are given in appendices 2 and 3 .

\section{Criteria for Determining Source of Gas}

Appendix 4 shows summary charts with geochemical and selected geologic horizions interpretations for all 35 wells in this study. Gas sources are mainly determined by the criteria of Bernard and others (1978). Thermogenic gas is defined as $\delta^{13} \mathrm{C}_{1}$ greater than -50 , and $\mathrm{C}_{1} / \mathrm{C}_{2}+\mathrm{C}_{3}$ ratios of less than 100 . Microbial gas is defined as $\delta^{13} \mathrm{C}_{1}$ less than -60 , and $\mathrm{C}_{1} / \mathrm{C}_{2}+\mathrm{C}_{3}$ greater than 1,000 . Values intermediate of these parameters are considered mixed. Other factors, mainly methane concentrations lower than $100 \mathrm{ppm}$ or $300 \mu \mathrm{L} / \mathrm{L}$, can skew both measurements, and these are considered in the interpretation. The geologic horizons of top of the gas hydrate stabilitiy zone (top GHSZ), base of the gas hydrate stabilitiy zone (base GHSZ), and base of ice-bearing permafrost (base PF) were taken from Collett and others (2009). The charts and maps used in this report interpolate the values the depth to the top, base, and thickness of the GHSZ and PF. These estimates were based on data from selected industry exploration wells and are compiled from geophysical logs of oil and gas wells, from down-hole temperature profiles, or subsurface temperature of $0^{\circ} \mathrm{C}$ as measured in borehole temperature logs. Permafrost depths are based on data from Osterkamp and Payne (1981), Lachenbruch and others $(1982 ; 1987)$, and Collett and others (1989). The gas hydrate thickness, top, and bottom were calculated assuming a structure-I methane hydrate with the thermal gradients established by the depth to base of permafrost. Geochemical information is superimposed on these horizons to display suggested horizons that predict gas sources and may contain methane hydrate. Analysis of horizons and projections of horizons mainly from the Prudhoe Bay region are given in table 2. Geothermal horizons (for example, top of gas hydrate) given in table 2 can be different from those given in table 1. For any well listed in both tables, values given in table 2 have a higher degree of accuracy.

The criteria determining gas sources and zones are somewhat subjective and use a combination of established geochemical parameters. For gas source the criteria of Bernard and others (1978) in the $\delta^{13} C_{1}$ versus the $C_{1} / C_{2}+C_{3}$ ratio for thermogenic gas is a combination of the $\mathrm{C}_{1} / \mathrm{C}_{2}+\mathrm{C}_{3}$ ratio, $\delta^{13} \mathrm{C}_{1}$ for $\mathrm{C}_{1}, \mathrm{C}_{2}, \mathrm{C}_{3}$, and so on, and presence of substantial concentrations of $\mathrm{C}_{3}$ or greater. Microbial gas is defined in a similar manner with the $\mathrm{C}_{1} / \mathrm{C}_{2}+\mathrm{C}_{3}$ ratio, $\delta^{13} \mathrm{C}_{1}$, and $\delta^{13} \mathrm{CO}_{2}$, the fractionation factor between $\delta^{13} \mathrm{C}_{1}$ and $\delta^{13} \mathrm{CO}_{2}$, and lack of substantial concentrations of $\mathrm{C}_{3}$ or greater. The dominant methane-generating process in the upper $1,000 \mathrm{ft}$ is $\mathrm{CO}_{2}$ reduction as shown by the carbon isotopic fractionation between coexisting methane and $\mathrm{CO}_{2}$ with fractionation factors of about 1.05 to 1.10 as defined by Whiticar and others (1986). Mixtures of these sources result in gray areas referred to as 
Table 2. Projected and well-log picked gas hydrate intervals in selected North Slope, Alaska, oil and gas wells analyzed by the U.S. Geological Survey and Bureau of Land Management with well-logging tools.

[See table 1 for well abbreviations; API, American Petroleum Institute; $\mathrm{C}_{1}$, methane; NA, not applicable; GL, ground level; IBPF, ice bearing permafrost.]

\begin{tabular}{|c|c|c|c|c|c|c|c|c|c|}
\hline Well & API & Lat $\left({ }^{\circ} \mathrm{N}\right)$ & Long $\left({ }^{\circ} \mathrm{W}\right)$ & $\begin{array}{l}\text { Top of } \mathrm{C}_{1} \text { hydrate } \\
\text { (ft from GL) }\end{array}$ & $\begin{array}{l}\text { Base of } \mathrm{C}_{1} \text { hydrate } \\
\text { (ft from GL) }\end{array}$ & $\begin{array}{l}\text { Base ice-bearing } \\
\text { permafrost } \\
\text { (ft from GL) }\end{array}$ & $\begin{array}{l}\text { Base permafrost } \\
\text { (ft from } \mathrm{GL})\end{array}$ & Notes regarding GH stability & $\begin{array}{c}\text { Gas hydrate occurrence (log } \\
\text { measured depth ft) }\end{array}$ \\
\hline KRU 2B-10 & 50029210840000 & 70.28937 & -149.93751 & 707 & 2,433 & 1,523 & NA & Map projected & No log evidence of gas hydrate \\
\hline KRU 2D-15 & 50029211840000 & 70.28401 & -149.76165 & 751 & 2,508 & 1,553 & NA & Map projected & No log evidence of gas hydrate \\
\hline KRU 3-A9 (WS 23) & 50029206990000 & 70.40368 & -149.93826 & 751 & 2,500 & 1,547 & NA & From IBPF pick in well & No log evidence of gas hydrate \\
\hline KRU 3-H9 & 50103200860000 & 70.41181 & -150.01174 & 747 & 2,573 & 1,600 & NA & Map projected & No log evidence of gas hydrate \\
\hline KRU 3-K9 & 50029216560000 & 70.43321 & -149.76079 & 744 & 2,643 & 1,650 & NA & Map projected & No log evidence of gas hydrate \\
\hline MPU E4 & 50029219970000 & 70.45542 & -149.43674 & 740 & 2,713 & 1,700 & NA & Map projected & $\begin{array}{l}\text { Unit C } 2,132-2,186 \mathrm{ft} \text {, Unit D } \\
2,016-2,060 \mathrm{ft} \text {; projected from Mount } \\
\text { Elbert } 1\end{array}$ \\
\hline PBU R-1 & 50029203530000 & 70.34547 & -148.91084 & 726 & 2,991 & 1,900 & NA & Map projected & No log evidence of gas hydrate \\
\hline PBU S-26 & 50029220470000 & 70.35359 & -149.03021 & 726 & 2,991 & 1,900 & NA & Map projected & No log evidence of gas hydrate \\
\hline PBU Z7 & 50029220460000 & 70.29769 & -149.19553 & 730 & 2,921 & 1,850 & NA & Map projected & $\begin{array}{l}\text { Possible gas hydrate } 2,200-2,900 \mathrm{ft} \mathrm{in} \\
2-3 \text { units? }\end{array}$ \\
\hline PBU Z8 & 50029217870000 & 70.29777 & -149.19959 & 730 & 2,921 & 1,850 & NA & Map projected & $\begin{array}{l}\text { Possible gas hydrate } 2200-2900 \mathrm{ft} \text { in } 2-3 \\
\text { units? }\end{array}$ \\
\hline KPU 1-R East & 50029232950000 & 70.39541 & -149.55907 & 740 & 2,713 & 1,700 & NA & Map projected & $\begin{array}{l}\text { Unit A } 1,980-2,010 \mathrm{ft} \text {, Unit B } \\
1,740-1,850 \mathrm{ft} \text {; projected from KRU } 1 \mathrm{H}-6\end{array}$ \\
\hline KPU 1-H South & 50029232960000 & 70.39486 & -149.55789 & 740 & 2,713 & 1,700 & NA & Map projected & $\begin{array}{l}\text { Unit A } 1,980-2010 \mathrm{ft} \text {, Unit B } 1,740-1,850 \\
\mathrm{ft} \text {; projected from KRU } 1 \mathrm{H}-6\end{array}$ \\
\hline Atlas 1 & 50103203600000 & 70.15183 & -150.55046 & 760 & 1,850 & 1,000 & NA & Map projected & $\begin{array}{l}1,000-1,300 \mathrm{ft} ; \text { projected from Tarn } \\
2 \mathrm{~N} 349\end{array}$ \\
\hline MPU S-15 & 50029230610000 & 70.40972 & -149.46630 & 725 & 3,005 & 1,910 & NA & From IBPF pick in well & $\begin{array}{l}\text { Unit B } 2,370-2,420 \mathrm{ft} \text {, Unit C } \\
2,021-2,047 \mathrm{ft}, \text { Unit } \mathrm{D} 1,980-2,015 \mathrm{ft} \text {, } \\
\text { Unit E } 1,864-1,910 \mathrm{ft} \text { Unit } \mathrm{F} \\
1,474-1,740 \mathrm{ft} \text { gas hydrate and ice } \\
\text { interbedded section }\end{array}$ \\
\hline MPU S I-16 & 50029232210000 & 70.43653 & -149.57800 & 740 & 2,713 & 1,700 & NA & Map projected & $\begin{array}{l}\text { Unit C } 1,715-1,770 \mathrm{ft}, \text { Unit D } \\
1,570-1,615 \mathrm{ft} \text {, Unit E } 1,430-1,455 \mathrm{ft} \text {; } \\
\text { projected from West Sak } 25\end{array}$ \\
\hline Mount Elbert 1 & 50029233020000 & 70.45559 & -149.41321 & 736 & 2,796 & 1,760 & NA & From IBPF pick in well & $\begin{array}{l}\text { Unit C 2,132-2,186 ft, Unit D } \\
2,016-2,060 \mathrm{ft}\end{array}$ \\
\hline KRU Tarn 2N-305 & 50103203490000 & 70.17132 & -150.31427 & 755 & 2,150 & 1,095 & NA & Map projected & $\begin{array}{l}1,095-1,375 \mathrm{ft} ; \text { projected from Tarn } \\
\text { 2N349 }\end{array}$ \\
\hline Thetis Island 1 & 50103201900000 & 70.55365 & -150.15287 & 750 & 2,500 & 1,550 & NA & $\begin{array}{l}\text { Projected from E. Harrison } \\
\text { Bay No. } 1\end{array}$ & No log evidence of gas hydrate \\
\hline Wainwright 1 & 50301200030000 & 70.64409 & -160.02373 & 790 & 1,738 & NA & 1,000 & Map projected & No log evidence of gas hydrate \\
\hline
\end{tabular}


mixed gas sources. Potential gas sources include microbial gas from organic matter degradation, oil-associated and nonassociated thermal gas, microbial and thermal gas from coalbeds, and gas from biodegraded oil deposits.

\section{Criteria for Inferring the Occurrence of Gas Hydrate}

The occurrence of gas hydrate is often inferred from the expression of a set of unique well-log responses as acquired in the course of normal oil and gas well drilling and development activities. However, it is also possible to infer the occurrence of gas hydrate by the presence of a unique set of geochemical signatures that can be attributed to the chemical makeup of gas hydrates.

Potential gas hydrate horizons are evaluated on subsets of geochemical criteria, with the addition of geologic information. The diagnostic ratios of $\mathrm{C}_{1} /\left(\mathrm{C}_{2}+\mathrm{C}_{3}\right), \mathrm{C}_{1} / \mathrm{CO}_{2}$, and iC $\mathrm{C}_{4} / \mathrm{nC}_{4}$ help identify possible gas hydrate occurrences in permafrost environments (Lorenson and others, 2005, 2009, 2011). Analyses of the gas hydrate accumulation of the Mallik wells in the Northwest Territories, Canada (Lorenson and others, 1999, 2005), showed that the $i \mathrm{C}_{4} / n \mathrm{C}_{4}$ ratio of gas hydrate increases substantially relative sediment without gas hydrate. Normally, the $\mathrm{iC}_{4} / \mathrm{nC}_{4}$ ratio is about 0.5 in most thermogenic gas (Alexander and others, 1983). In contrast, in the gas hydrate zone, this ratio commonly exceeds 1 . It was thought that this effect reflects the scavenging of $i \mathrm{C}_{4}$ into disseminated pockets of structure-II gas hydrate within a deposit of mainly structure-I gas hydrate. Small amounts of structure II gas hydrate are possible in deposits containing mainly structure-I gas hydrate.

The gas dryness ratio $\mathrm{C}_{1} /\left(\mathrm{C}_{2}+\mathrm{C}_{3}\right)$ is useful because methane hydrate can concentrate methane relative to other hydrocarbon gases, resulting in higher values relative to the surrounding sediment (Lorenson and others, 1999). Another useful parameter in this environment is the $\mathrm{C}_{1} / \mathrm{CO}_{2}$ ratio. In similar manner, it appears that more methane relative to $\mathrm{CO}_{2}$ is used in hydrate formation resulting in higher $\mathrm{C}_{1} / \mathrm{CO}_{2}$ ratios for gas hydrate than in the surrounding sediment.

Coal or lignite can give the same geochemical response as gas hydrate, and analysis of density/resistivity from well logs is needed to verify the presence of gas hydrate. Our interpretations take into account known regional geologic and geochemical trends. To verify the occurrence of gas hydrates, other techniques such as wire-line logging and coring are needed as confirmation.

\section{Discussion}

\section{Geologic Setting of the North Slope}

The North Slope is a composite basin consisting of an upper Paleozoic and Mesozoic south-facing passive-continental-margin sequence and an upper Mesozoic and Cenozoic north-facing foreland-basin sequence. The foreland basin sediments derived from a southern source, the Brooks Range orogen. These rocks, known as the Brookian sequence, overlie Mississippian to Upper Cretaceous continental margin deposits known as the Ellesmerian and Beaufortian sequences (fig. 2). The Ellesmerian sequence rocks were deposited on the south-facing margin of a stable continental landmass. Together, the Brookian and Ellesmerian and overlying Beaufortian sequences make up the composite basin deposits, which unconformably overlie metamorphosed sedimentary and igneous basement rocks of Proterozoic to Devonian age.

The Ellesmerian sequence contains both petroleum source and reservoir rocks. The source rocks, which lie near the top of the sequence, did not generate petroleum north of the Brooks Range until buried by Beaufortian and Brookian deposits. The Jurassic and Lower Cretaceous Beaufortian sequence consists of synrift deposits derived locally or from the north. It is a stratigraphically complex, mud-dominated sequence with multiple unconformities and large variations in thickness and contains petroleum source and reservoir rocks.

Uplift and erosion along the rift margin created the Lower Cretaceous Unconformity (LCU). The LCU, which progressively truncates older rocks northward, is partly responsible for many of the largest oil accumulations in northern Alaska by providing a hydrocarbon-migration pathway for charging multiple reservoirs below the unconformity. Cretaceous mudstone overlying the unconformity serves as a seal, creating combination structural-stratigraphic traps, such as at the Prudhoe Bay oil field.

Cretaceous and Tertiary deposits derived from the Brooks Range orogen are known as the Brookian Sequence that filled the Colville foreland basin, spilled over the rift shoulder, and built the passive margin that forms the modern continental terrace north of Alaska. The Brookian sequence consists of a complex assemblage of siliciclastic strata that include distal, condensed marine mudstone (Hue Shale); relatively deep marine basinal, slope, and outer-shelf mudstone and turbidite sandstone (Torok, Seabee, and Canning Formations); and deltaic shallow-marine to coal-bearing nonmarine sandstone, mudstone, and conglomerate (Nanushuk, Tuluvak, Prince Creek, Schrader Bluff, and Sagavanirktok Formations). Organic-rich beds of the Hue Shale are important oil source rocks. Reservoir rocks consist of turbidite and shallow-marine to nonmarine sandstone, and known oil and gas accumulations occur in both structural and stratigraphic traps within the Brookian sequence. Sediment accumulation in the Colville Basin and on the passive margin north of the Barrow Arch generally progressed from west to east during the Cretaceous and Cenozoic time. Deposition of a thick Brookian sequence provided the overburden necessary for thermal maturation of petroleum source rocks located in Ellesmerian, Beaufortian, and Brookian strata. Oil generation and most gas generation were complete across NPRA by about 90 million years ago. Thus, at the time of Cenozoic uplift and erosion, it is likely 


\section{Stratigraphic Column Alaska North Slope}

\section{Stratigraphic Column NPRA Region and Milne Point Unit}

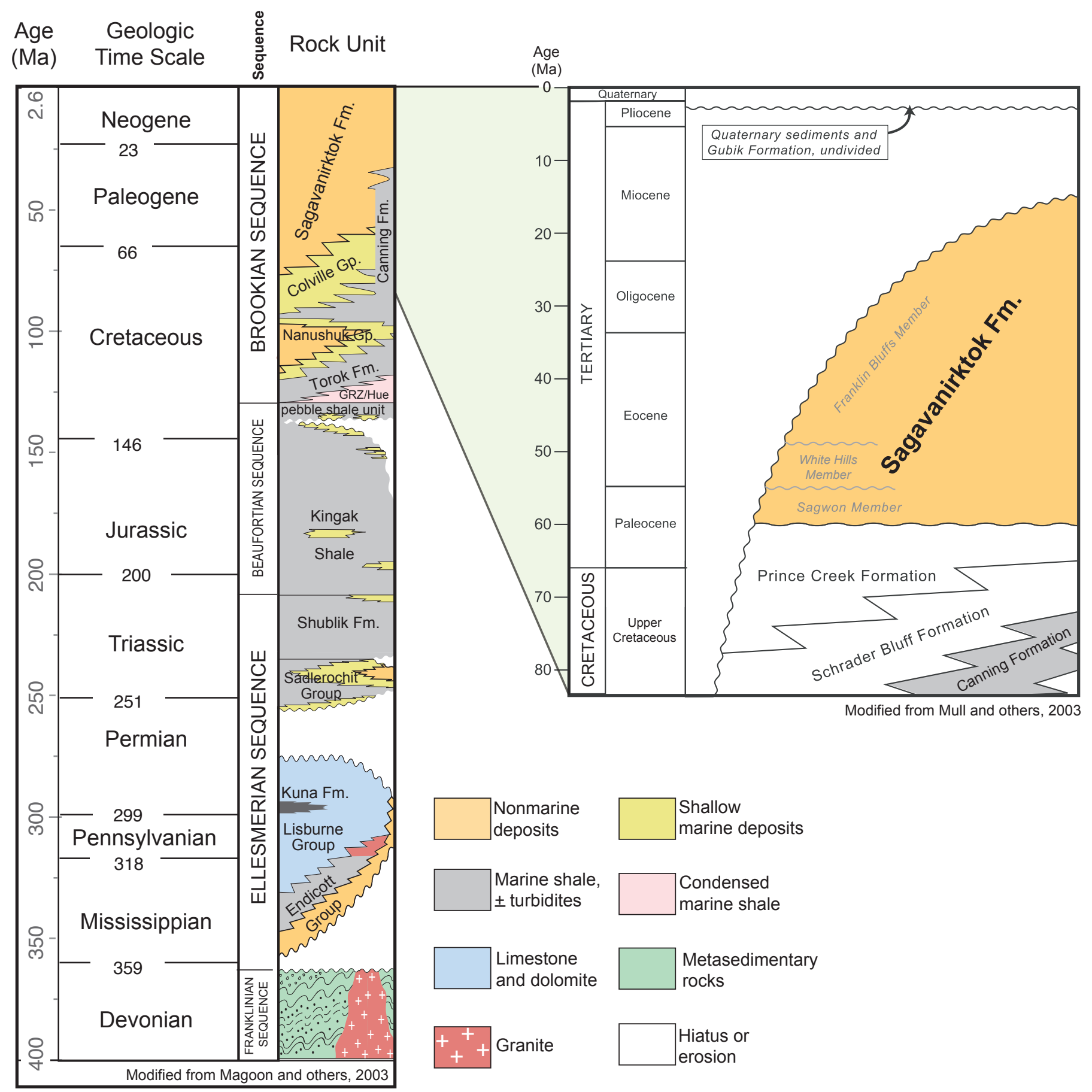

Figure 2. Generalized stratigraphic column for the North Slope of Alaska. The Saganavirktok Formation, expanded in the lithostratigraphic column, is the primary reservoir for gas hydrate in the Eileen and Tarn areas. Oil and gas accumulations are found throughout the stratigraphic section. Modified from Bird (2001), Magoon and others (2003), and Mull and others (2003). 
that oil was present in various reservoirs in northern NPRA, where the source rocks experienced lower thermal maturity. Gas was likely present in reservoirs in southern NPRA, where source rocks experienced higher thermal maturity. In areas of modest uplift in northeastern NPRA, degassing of oil accumulations likely generated gas caps and displaced oil downward into poorer quality reservoir rocks (for example, SparkRendezvous A fields, fig 1). In areas of moderate uplift in northwestern NPRA and significant uplift in southern NPRA, degassing of oil combined with significant gas expansion likely caused a gas "flush" outward, away from the uplifted areas (Housekneckt, 2010).

\section{Petroleum Systems of the North Slope}

The USGS has adopted the concept of petroleum systems to evaluate the resource potential of northern Alaska, under the concept of the total petroleum system (TPS). The geologic elements within a TPS are hydrocarbon source rocks (maturity, hydrocarbon generation, migration), the characteristics of reservoir rocks, trap and seal formation, and the timing of all these events. The coalbed gas assessment units (AUs) within the North Slope TPS include the Nanushuk Formation AU, the Prince Creek and Tuluvak Formations AU, and the Sagavanirktok Formation AU shown in figure 3.
Magoon and others (2003) have described six petroleum systems for the North Slope of Alaska, three of which are pertinent to the gas hydrate system in NPRA. The terminology used lists the source rock followed by the reservoir rock using the convention of Magoon and Dow (1994); for example, in the Shublik-Ivishak petroleum system, the Shublik Formation is referred to as the source rock and the Ivishak Formation is referred to as the reservoir rock. The largest potential source area in NPRA is the hypothetical Gamma ray zone (GRZ)/ Pebble shale unit/Torok-Nanushuk Cretaceous oil. The source rocks were active from about 105 to $90 \mathrm{Ma}$, and known oil fields and pools include the Tarn pool, Kuparuk oil field, Fish Creek seep, Walakpa field (south of Barrow, Alaska). Oil shows in wells occur along the northern Alaska coastline. Any oil and gas generated by this petroleum system must be preserved for $90 \mathrm{Ma}$ after generation and migration.

The hypothetical Kuna-Lisburne petroleum system has produced gas in the South Barrow, and Walakpa fields. Hydrocarbons were generated during Jurassic to Early Cretaceous (175? to $130 \mathrm{Ma}$ ), and thus preservation of the oil and gas is less likely. It is assumed this petroleum system is volumetrically unimportant. The most important petroleum system known in NPRA is the Kingak-Alpine, responsible for charging the Alpine field, and to some extent it contributes to the Prudhoe Bay and Lisburne fields. The oil produced is high gravity ( $39^{\circ} \mathrm{API}$ gravity) and low sulfur ( $0.3 \mathrm{wt}$ percent), and

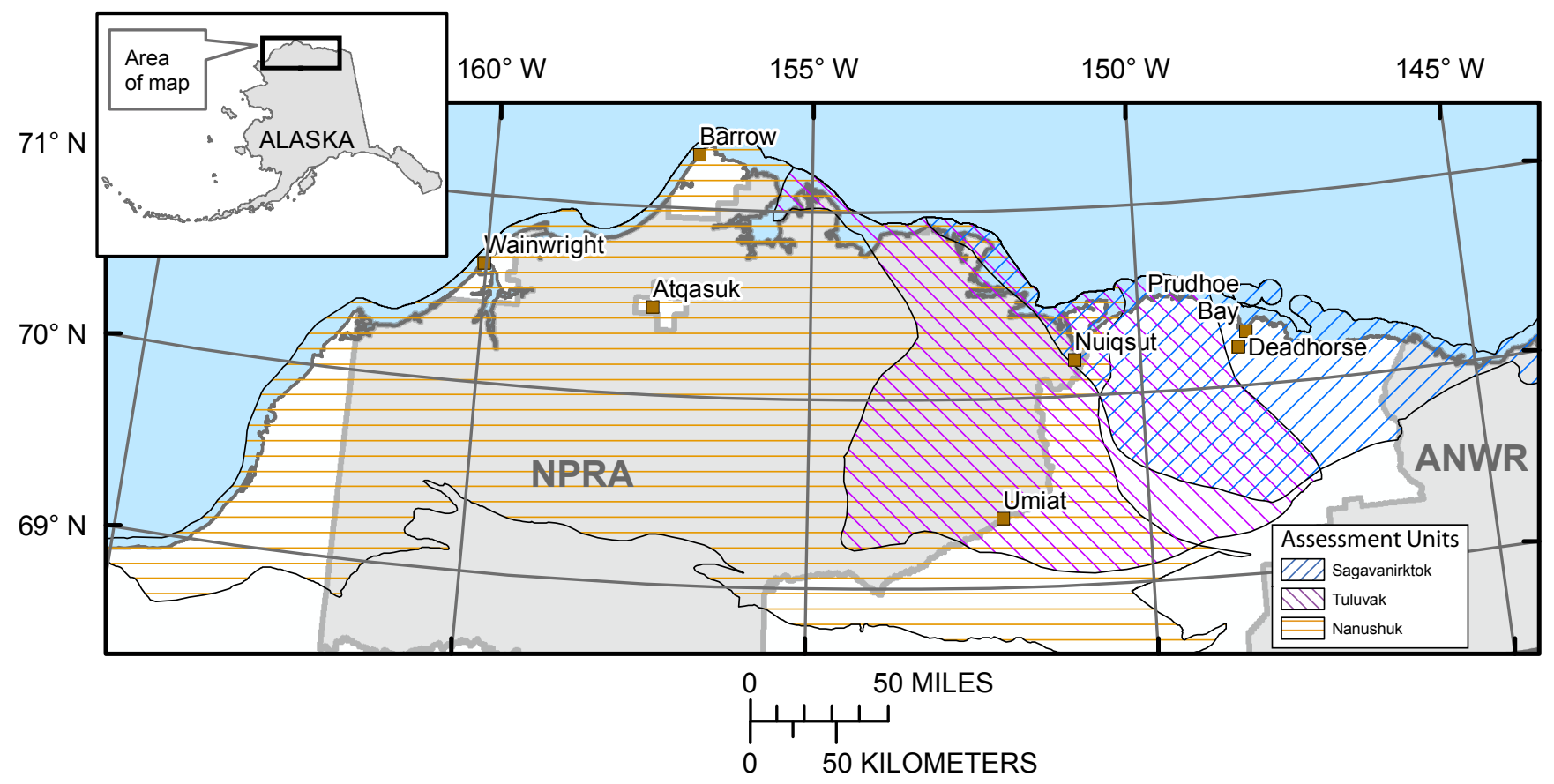

Figure 3. Map of the North Slope of Alaska showing extent and location of the Brookian Coalbed Gas Composite Total Petroleum System (TPS), and areas within each assessment unit (AU) in the TPS that were assessed for coalbed-gas potential in Cretaceous and Tertiary rocks, North Slope and adjacent State waters, Alaska. Assessment units (AUs) within the North Slope TPS are the Nanushuk Formation AU, the Prince Creek and Tuluvak Formations AU, and the Sagavanirktok Formation. NPRA, National Petroleum Reserve in Alaska; ANWR, Arctic National Wildlife Refuge. 
the volume is estimated to be 2.9 gigabarrels of oil equivalent (GBOE) (Magoon and others, 2003). The active hydrocarbon generation took place between 80 and $40 \mathrm{Ma}$, making preservation of oil and gas much more likely.

Outside NPRA, three other petroleum systems occur, the most important of which is the Shublik-Ivishak petroleum system that produced hydrocarbons for the West Sak, Kuparuk, Prudhoe Bay, Lisburn, Mikkelson, Badami, and Flaxman fields (13.58 GBOE). The Shublik Formation is responsible for 59 percent of the oil in the greater Prudhoe Bay region; the Hue and Kingak shales are responsible for the remaining hydrocarbons that result in the $1.6 \mathrm{wt}$ percent sulfur, $23^{\circ}$ API gravity oil found in the Kuparuk field. The hydrocarbons are stored in 12 sandstones of Mississippian to Paleogene age. The oil associated with the Fish Creek field is the only oil in NPRA sourced from the Shublik Formation. The active hydrocarbon generation took place between 80 and $40 \mathrm{Ma}$, making preservation of oil and gas much more likely. The remaining two systems are the hypothetical Hue-Thompson and the offshore speculative Canning-Sagavanirktok petroleum systems that are east of NPRA.

The North Slope gas hydrate deposits are related to the above petroleum systems with evidence of oil migration, oil biodegradation, and generation of $\mathrm{C}_{1}$ to $\mathrm{C}_{3}$ from biodegraded oil or gas (Lorenson and others, 1999, 2005, 2009, 2011). These studies have shown that gas hydrate and permafrost are partial barriers to gas migration and enhance isotopic partitioning of hydrocarbon gases. Until now, only gas hydrates of the Eileen and Tarn accumulations have been evaluated; however, the results of this study expand these concepts westward in to NPRA. Of further interest is the potential impact of coalbeds, both as a source for gas hydrate methane and as a lithology capable of hosting gas hydrate.

\section{Coalbed Gas}

The USGS defined the Brookian Coalbed Gas Composite TPS (Roberts, 2008; fig. 3) to include that area of the North Slope and adjacent State waters underlain by Cretaceous and Tertiary strata containing coal deposits with the potential for undiscovered coalbed-gas resources. Currently, there is no production of coalbed methane on the North Slope. The assessment units are identical to those of the gas hydrate assessment units of Roberts, (2008). The Nanushuk Formation Coalbed Gas AU, in the western and central part of the North Slope, includes a large part of the NPRA. Coalbeds in the AU are distributed over the largest area relative to the other AUs. Discontinuous outcrops of the Nanushuk Formation, which are present in the southern part of the AU, contain coalbeds as much as $20 \mathrm{ft}$ thick; cumulative (total) coal thickness locally exceeds $200 \mathrm{ft}$. Data from numerous oil and gas exploration wells penetrating coal-bearing strata within the formation indicate the presence of gas in close association with coalbeds (for example, see Collins, 1958; Tyler and others, 2000). More recently, gas of the Nanushuk
Formation coalbeds was documented in a shallow core hole (total depth 1,613 ft) (fig. 2) drilled in 2007 in the village of Wainwright (fig. 1). The range in thermal maturity of Nanushuk Formation coal $\left(\mathrm{R}_{\mathrm{o}}\right.$ from about 0.40 to almost 1.0 percent) would allow for the generation and accumulation of both biogenic (microbial) gas or thermogenic gas or both; significant thermal gas generation in coal (type-III organic matter) is thought to occur at $R_{o}$ levels above $0.73-0.80$ percent (Johnson, 1989).

The Prince Creek and Tuluvak Formations Coalbed Gas AU is located in the central part of the North Slope and includes the easternmost part of NPRA. The Tuluvak and Prince Creek Formations have a cumulative (total) coal thickness that exceeds $70 \mathrm{ft}$, and individual beds are as thick as $15 \mathrm{ft}$. The potential for coalbed-gas resources in the Prince Creek and Tuluvak Formations is lessened by having low thermal maturity and significantly smaller accumulations of coal, particularly below permafrost, relative to the Nanushuk and Sagavanirktok Formations.

The Sagavanirktok Formation Coalbed Gas AU, located in the central and eastern part of the North Slope, includes the coastal plain part of the Alaska National Wildlife Refuge (ANWR). Coal outcrops are present along riverbanks in the southern part of the AU (fig. 3). Total coal thickness exceeds $180 \mathrm{ft}$ locally, with individual coalbed thicknesses of as much as $35 \mathrm{ft}$. The Sagavanirktok Formation includes a significant volume of coal; however, the generally low thermal maturity of the coalbeds (Ro $<0.60$ percent) would likely produce little thermal gas. Roberts (2008) indicates that much of the Sagavanirktok Formation coalbed-gas potential relies on biogenic gas generation, with some possibility of a thermogenic gas component that has migrated into coalbeds from older and more deeply buried noncoal source rocks in the Kuparuk River area to the west of Prudhoe Bay.

\section{Gas Hydrate Resources of the North Slope}

Gas hydrates are stable over much of northern Alaska (fig. 4). Collett and others (2008) prepared an assessment of gas hydrate resources within three new assessment units: the Nanushuk Formation Gas Hydrate AU (Cretaceous), the Prince Creek and Tuluvak Formations Gas Hydrate AU (Cretaceous to Tertiary), and the Sagavanirktok Formation Gas Hydrate AU (Tertiary), similar in extent to those of the coalbed gas AUs shown in figure 3 . The total amount of gas hydrate expected to be technically recoverable ranges from between 25.2 to 157.8 trillion cubic feet (TCF), with a mean estimate of 85.4 TCF. A mean estimate of 36.9 TCF is expected in the Nanushuk Formation gas hydrate AU, and this area mainly occurs within NPRA. About 28.0 TCF is within the Tuluvak-Schrader Bluff-Prince Creek Formations Gas Hydrate AU, also mainly in NPRA, and about 20.6 TCF is in the Sagavanirktok Formation Gas Hydrate AU. The best known gas hydrate deposits are from the Sagavanirktok Formation Gas Hydrate AU and are divided into the Eileen and Tarn accumulations. 


\section{Eileen Gas Hydrate Accumulation}

Gas hydrates are inferred to occur in an additional 50 exploratory and production wells in northern Alaska on the basis of downhole log responses calibrated to the known gas hydrate occurrences in the ARCO/Exxon 2 Northwest Eileen State well (Collett, 1993) (fig. 5A). Figure 5B shows a section across the Prudhoe-Kuparuk area with well logs. Many of these wells have multiple gas hydrate-bearing units, with individual occurrences ranging from about 10 to $100 \mathrm{ft}$ thick. Most of the well-log-inferred gas hydrates occur in six laterally continuous sandstone and conglomerate units; all are geographically restricted to the area overlying the eastern part of the Kuparuk River field and the western part of the Prudhoe Bay field.

The six gas hydrate-bearing sedimentary units of the Eileen trend have each been assigned a reference letter, units A-F, with unit A being the stratigraphically deepest (fig. 5B). Three-dimensional seismic surveys and downhole logs from wells in the western part of the Prudhoe Bay field indicate the presence of several large free-gas accumulations trapped stratigraphically downdip below four of the log-inferred gas hydrate units. The total mapped area of the six gas hydrate occurrences within the sand units is about $1,643 \mathrm{~km}^{2}$; the areal extent of the individual sand units ranges from 3 to 404 $\mathrm{km}^{2}$. The volume of in-place gas within the gas hydrates of the Prudhoe Bay-Kuparuk River area is estimated to be about
37 to 44 TCF $\left(1.0-1.2\right.$ trillion $\left.\mathrm{m}^{3}\right)$ or about twice the volume of known, in-place conventional gas in the Prudhoe Bay field (Collett, 1993; Collett, 2002).

The well geochemistry chart (fig. 6) for the Mount Elbert 1 well represents the best known gas hydrate accumulation on the North Slope. Details of the geochemistry can be referred to in Lorenson and others (2011), and details of the geologic setting can be referred to in Boswell and others (2011). Figure 6 shows a plot of methane $\left(\mathrm{C}_{1}\right)$, along with the gas wetness ratio $\left(\mathrm{C}_{1} /\left(\mathrm{C}_{2}+\mathrm{C}_{3}\right)\right)$ and carbon isotopic composition $\left(\mathrm{d}^{13} \mathrm{C}\right)$ of cuttings gases versus depth in the Mount Elbert well. Important geologic horizons are noted. In general the concentrations of most gases increases in or below the gas hydrate bearing units and the methane source is likely from a mixture of microbial, methane derived from biodegraded oil, and thermogenic gas (Lorenson and others, 2011). Sand unit B is water saturated, but the methane charge insufficient to generate gas hydrate. A series of thin coal units from about 2,890 to $2,970 \mathrm{ft}$ ( 880 to $905 \mathrm{~m}$ ) and potentially more below may be the major source of methane as well as other gases. The gas concentration data show that the base of permafrost is not an important barrier to advection of gases, (Lorenson and others, 2011). Logging tools indicate that organic-rich layers at about 650 and $2,742 \mathrm{ft}$ (200 and $836 \mathrm{~m}$ ) may be local sources for high concentrations of methane.

Methane isotopic composition from cuttings is very light above $656 \mathrm{ft}(200 \mathrm{~m})$, mixing with deeper sources below a

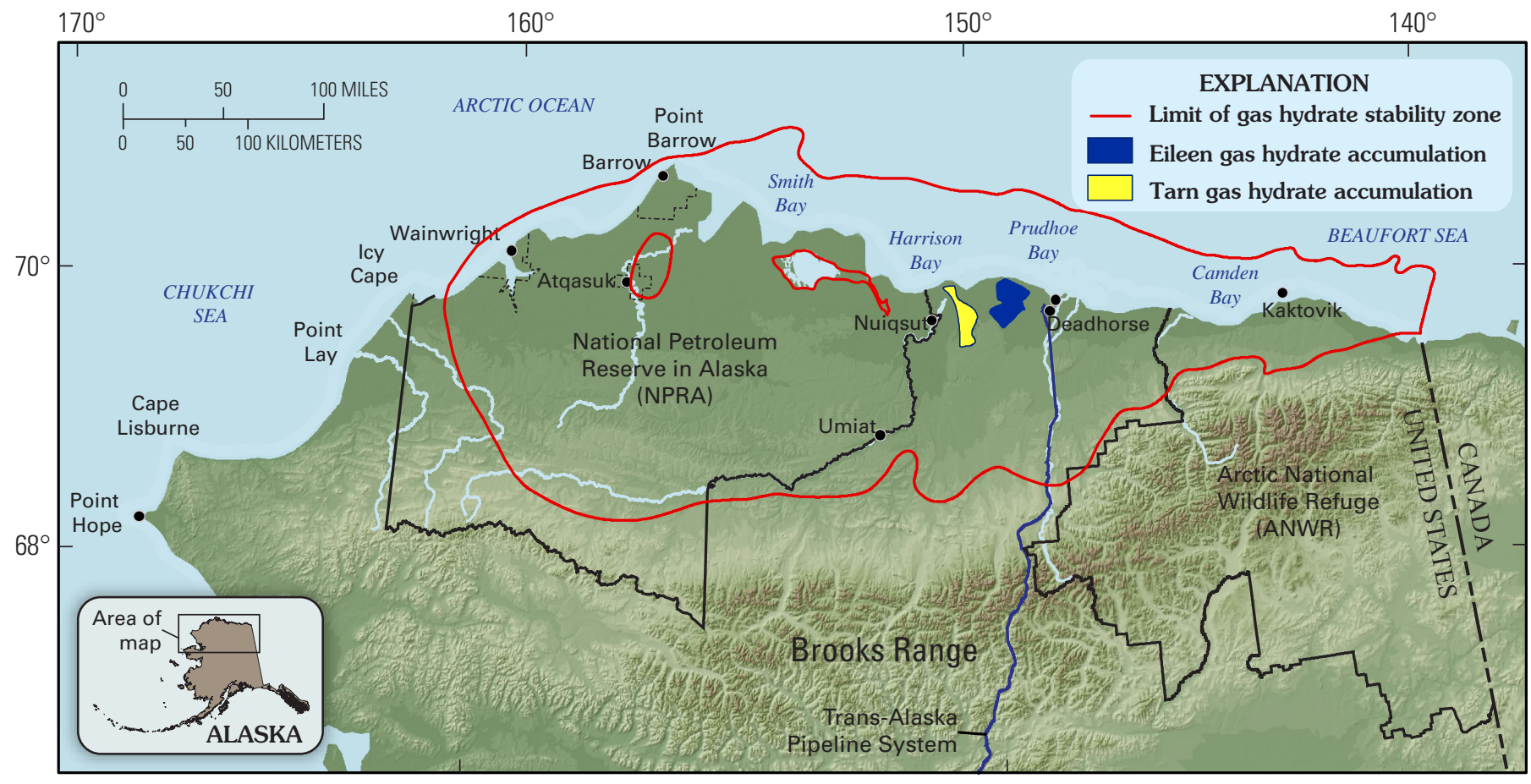

Figure 4. Area of potential gas hydrate occurrences in northern Alaska. Within this broad region the gas hydrate stability field exists both onshore and offshore (shown in red outline) and extends eastward into the Mackenzie Delta region of Canada (Collett, 1993, Collett and others, 2009). The Eileen and Tarn gas hydrate accumulations are shown in blue and yellow, respectively. 


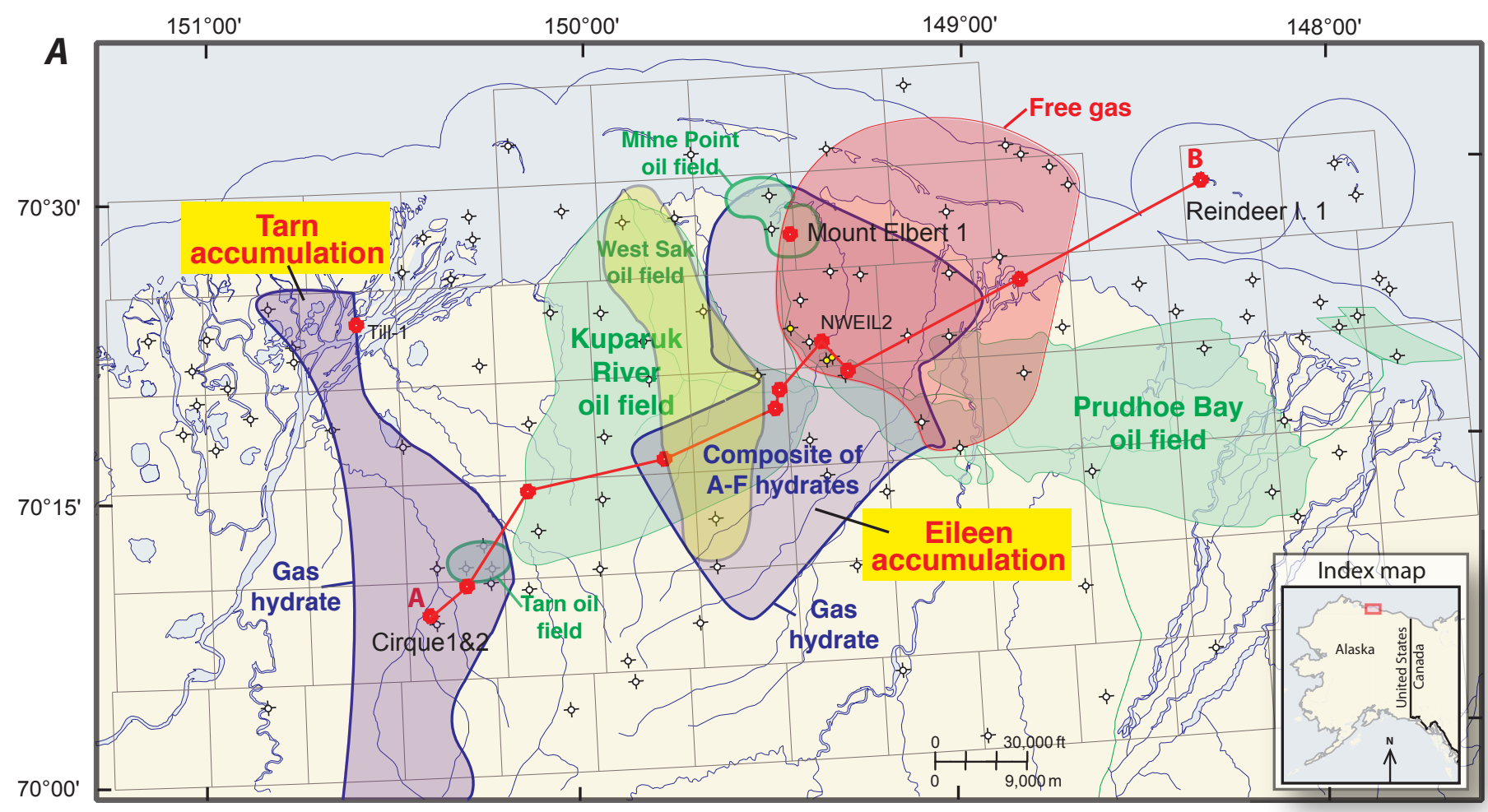

B

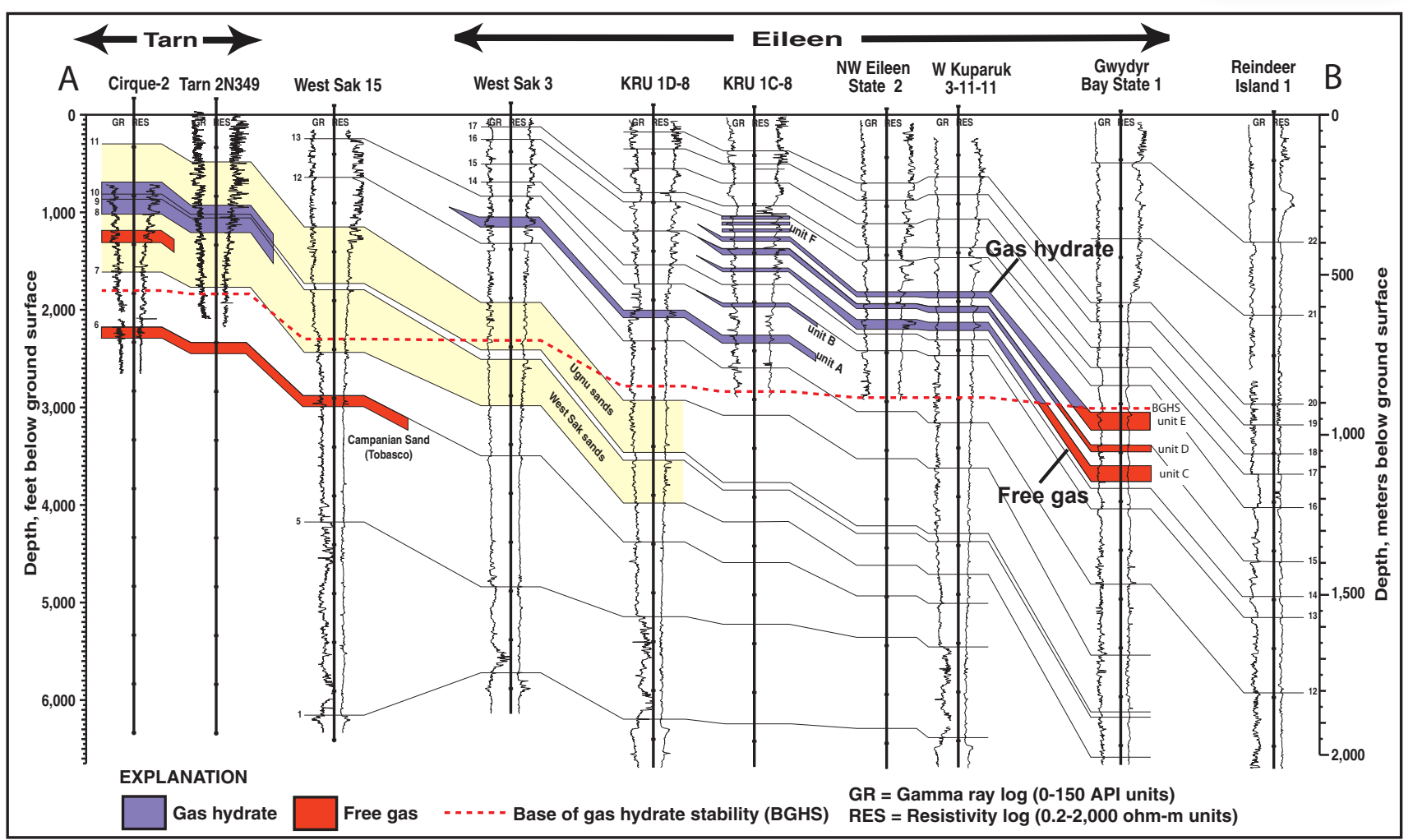

Figure 5. Partial map of the North Slope of Alaska $(A)$ showing the location of the cross section $(B)$, major petroleum fields in green, gas hydrate accumulations in blue, and free gas in red. $B$ shows the southwest to northeast well-log cross section across the Prudhoe BayKuparuk River area. Gas hydrates are shown in pink, whereas the underlying free gas is shown in red. The Eileen gas hydrates of the Kuparuk River oil field occur in six laterally continuous Tertiary sand units (units A-F), with individual occurrences ranging from 10 to 100 $\mathrm{ft} \mathrm{thick.} \mathrm{The} \mathrm{Mount} \mathrm{Elbert} \mathrm{No.} 1$ well penetrated units B-D. No gas hydrate occurs in unit B here. Gas hydrates of the Tarn and Cirque oil fields occur in older Upper Cretaceous units of the Ugnu and West Sak sands of Molenaar and others (1986) and reach thicknesses of about $160 \mathrm{ft}$. 


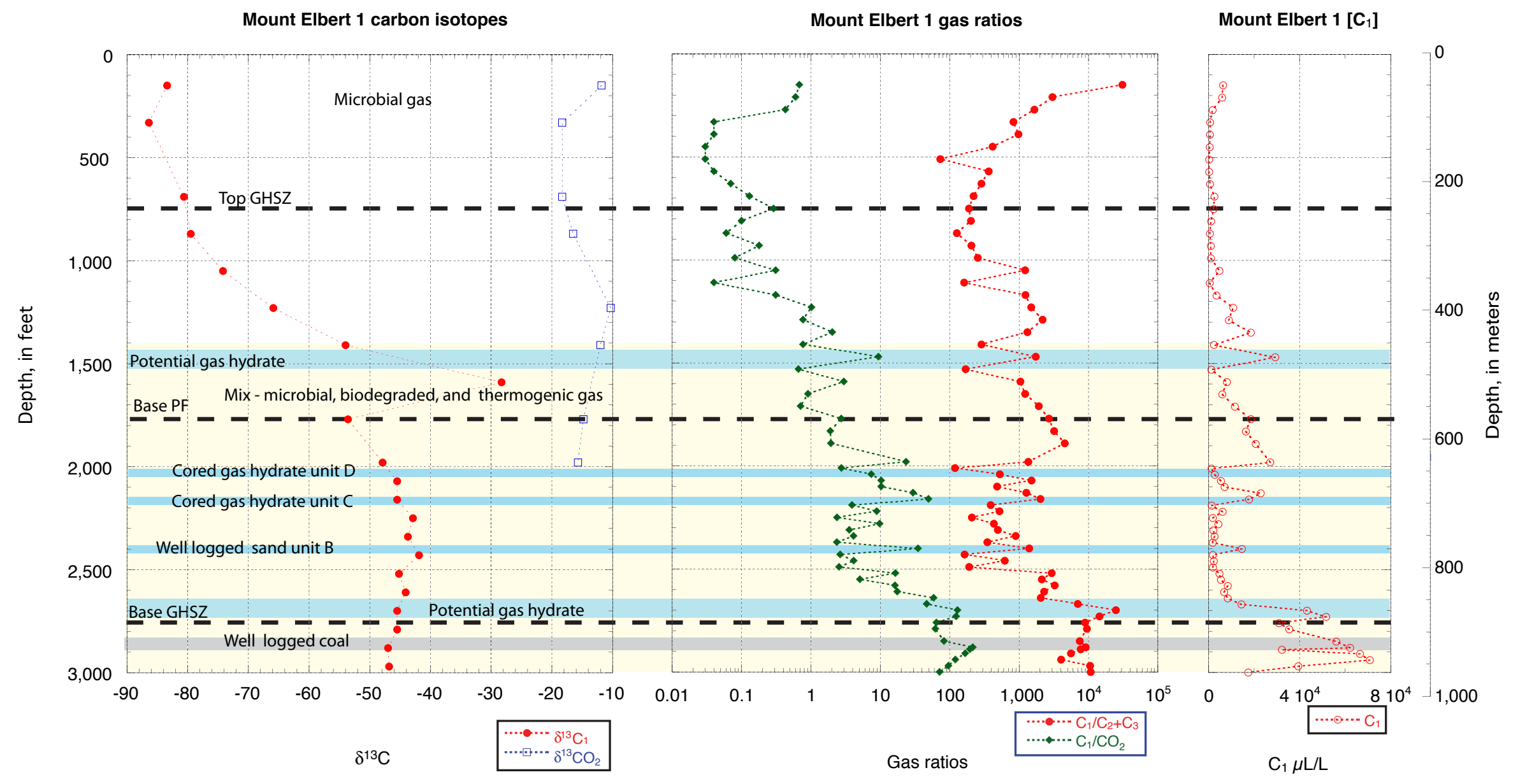

Figure 6. Geochemical data from the Mount Elbert 1 well (see fig. 1 for location). Parameters as described in text. Methane concentration units are given in the units of milliliters gas/liters sediment (mL gas/L sediment). GHSZ, gas hydrate stability zone. 
transition depth of about $1,310 \mathrm{ft}(400 \mathrm{~m})$. Below $1,968 \mathrm{ft}$ $(600 \mathrm{~m})$ the isotopic composition becomes consistent and ranges from about -48 to $-42 \%$. Because of the detailed well logging, coring, and gas hydrate recovery at the Mount Elbert 1 well, we can evaluate the geochemical criteria for predicting the possibility of gas hydrate at wildcat wells with those of a known gas hydrate accumulation.

Potential gas hydrate is noted in two horizons centered around 1,500 ft and 2,742 ft, where well logging has shown that no gas hydrate exists, but unusual zones of organicrich sediments do occur here. The known gas hydrate unit $\mathrm{C}$ is predicted by the geochemical criteria, whereas there is equivocal evidence for gas hydrate unit $\mathrm{D}$ due to the insufficient resolution of the data. The known coal horizon below the base of gas hydrate stability is easily detected by our criteria and, if it were within the gas hydrate stability zone would be considered a potential gas hydrate-bearing horizon. Integrating the results of this analysis demonstrates that the criteria for predicting potential gas hydrate is not exclusively predicting the presence of gas hydrate but rather is identifying geochemical environments where gas hydrate occurrence is favored.

The wells evaluated in stage 1 of this study mainly occur in the Eileen trend and collectively resemble the geochemical potential, gas hydrate occurrences, and gas sources described for the Mount Elbert 1 well. Wells evaluated in stage 2 within or nearby the Eileen gas hydrate accumulation are MPU S-15 and MPU S I-16, which have similar stratigraphy to the Mount Elbert 1 well and three wells to the south, KRU 1HSouth, KRU 1R-East, and Antigua 1.

\section{Tarn Gas Hydrate Accumulation}

Gas hydrate-bearing deposits as much as about $160 \mathrm{ft}$ thick occur to the west of the Eileen gas hydrate deposits in the Tarn gas hydrate accumulation. Geologic data from well logs indicate that Tarn gas hydrates occur in the informally named West Sak and Ugnu sands.

To the east, in the Kuparuk River oil field area, these oil-bearing sands have been extensively described by Werner (1987). They are estimated to contain more than 40 billion barrels (bbl) of in-place, low-gravity oil. The Upper Cretaceous West Sak interval ( $\sim 400$ to $500 \mathrm{ft}$ thick) represents transitional inner shelf and delta-front deposits. The West Sak consists of very fine- to fine-grained sandstone and silty sandstone with interbedded siltstone and mudstone. The West Sak interval is separated from the overlying Ugnu interval by a regionally extensive marine ( $\sim 100-130 \mathrm{ft}$ thick) mudstone. The Upper Cretaceous-lower Tertiary Ugnu interval ( $\sim 330-660 \mathrm{ft}$ thick) consists of a series of interbedded sandstones and mudstones. Interbedded coal in 1- to 2-ft-thick seams occurs locally, but coalified fragments of wood and other plant debris are common throughout.

The Tarn 2N-305 well chart (fig. 7, appendix 4) also shows a similar set of data to the Mount Elbert 1 well, where our criteria suggest gas hydrate occurs over a broad zone just below the base of permafrost from a depth of about 1,095 to $1,375 \mathrm{ft}$ (table 2). The thick gas hydrate layer accentuates the diagnostic ratios of $\mathrm{C}_{1} / \mathrm{C}_{2}+\mathrm{C}_{3}, \mathrm{C}_{1} / \mathrm{CO}_{2}$ and $\mathrm{iC}_{4} / \mathrm{nC}_{4}$ that we use to predict the occurrence of gas hydrate here and elsewhere. A transition occurs within the gas hydrate-bearing sections where the carbon isotopic composition of methane becomes heavier with depth, from -54 to $-48 \%$. Because the projected gas hydrate occurrence is substantially thick, isotopic filtration of methane occurs between the base of gas hydrate occurrence and above the top of the gas hydrate stability zone (GHSZ). Isotopic filtration is the process by which a semi-impermeable medium inhibits the flow of isotopically heavier molecules. In this case, it is thought that gas hydrate- and permafrostbounded sediment can act as a partial barrier to gas migration. The same effect was noted at the Mallik site in Canada (Lorenson and others, 1999, 2005), where not only methane was isotopically filtered but $\mathrm{C}_{2}, \mathrm{C}_{3}$, and $i \mathrm{C}_{4}$ were isotopically filtered as well.

Mixed or modified thermogenic gas is found in the gas hydrate-bearing sediment, in the gas hydrate itself, and in deeper strata down to the depth of the oil and gas deposits. This zone is characterized by a heavier carbon isotopic composition for methane $(-51$ to $-39 \%$, mean $-48.7 \%$, $n=38)$ and higher concentrations of methane, as well as higher concentrations of $\mathrm{C}_{2+}$ hydrocarbons (appendix 3, Tarn 2N-305 table). The average methane isotope in this zone is characteristic of methane sourced from biodegraded oils by way of the carbonate reduction pathway ( -45 to $-55 \%$ coupled as described by Head and others, 2003). Thus, although ultimately from a thermogenic source, the methane has likely been produced as the result of microbial degradation of oil. Below this zone of mixed-source gases, thermogenic gas is typically encountered at depths below about 3,500 $\mathrm{ft}$ in the Tarn field. However, we saw only partial evidence of a typical thermogenic-gas signature at the bottom of this well. Other thermogenic sources for gas may be local areas rich in coal or lignite. Potential gas hydrate-bearing horizons are both above and below the main gas hydrate horizon; however, the amplitude of each of the critieria parameters is less, suggesting either less gas hydrate or detection of some other organic-rich horizon. Other wells that are nearby or within the Tarn gas hydrate accumulation are Atlas 1 and Placer 1. Both of these wells have a thick potential gas hydrate zone similar to the Tarn $2 \mathrm{~N}-305$ well. Using the observations gained from better analyzed wells, we can now apply these criteria to the particular geologic settings in NPRA.

\section{Exploration in NPRA and Potential Gas Hydrate Accumulations}

Gas hydrate occurrences in NPRA are completely unknown. However, on the basis of only geochemical data, we speculate that there are 8 wells with potential gas hydrate, 6 wells with limited equivocal geochemical evidence, and one well with no evidence for gas hydrate (Scout 1, outside of the gas hydrate stability zone) (table 1). Equivocal evidence for 


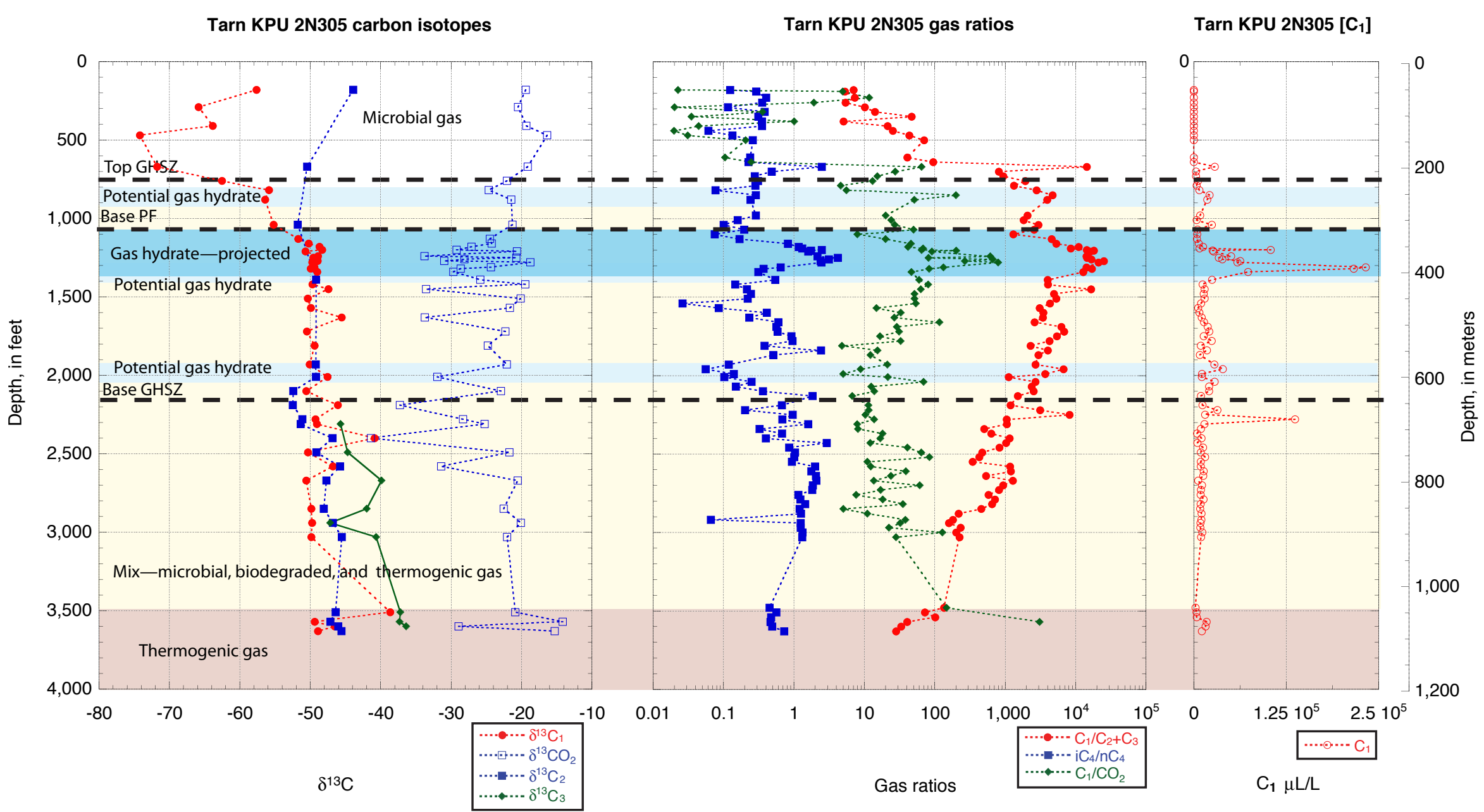

Figure 7. Geochemical data from the Tarn $2 \mathrm{~N}-305$ well (see fig. 1 for location). Parameters as described in text. Methane concentration units are given in the units of milliliters gas/liters sediment (mL gas/L sediment). GHSZ, gas hydrate stability zone. 
gas hydrate is determined by the occurrence of most but not all of the gas hydrate geochemistry proxy measurements, offsets in depth of the peak concentrations or ratios, and apparent but modest changes of concentration or ratio amplitude. The results of our analysis of geochemical conditions favorable to the occurrence of gas hydrate throughout northern Alaska are shown in figures 8 and 9. Thermogenic oil and gas deposits favor the occurrence of gas hydrate stratigraphically above any particular field; thus, it is prudent to predict the gas source based on well geochemistry. Figure 10 depicts the presence or absence of theromgenic gas and mixtures of thermogenic gas. We have determined that there are 9 wells with thermogenic gas or a mixture of thermogenic and mixed-source gases, 4 wells with limited (some equivocal geochemical evidence), and 2 wells with no evidence for thermogenic gas (table 1). Most of the data from these wells are taken from depths of $3,000 \mathrm{ft}$, depths far above a the geothermal horizons where any cracking might occur, thus the results are more relevant to thermogenic hydrocarbons that are migrating from below into these depths.

Many exploration wells drilled during recent eastern NPRA exploration are near the Alpine oil field and targeted the Alpine sandstone. The wells evaluated here are Iapetus 1, Spark 4, Spark DD9, Carbon 1, Scout 1, and Pioneer 1.

Five discoveries of oil have been reported in the Alpine sandstone in northeastern NPRA (Housekneckt and others, 2010). The geographic distribution of hydrocarbons favor the occurrence of oil to the east and gas to the west. Burruss and others (2002) noted the potential for a significant volume of microbial gas in the Alpine field, an observation that constitutes the only evidence for biodegraded oil west of the Tarn gas hydrate accumulation.

Cenozoic uplift and erosion from about 60 to 15 million years ago of the Brooks Range foothills in southern NPRA and of a broad area in northern NPRA may provide an explanation for the unanticipated predominance of gas in the Alpine sandstone and other strata (Housekneckt and others, 2010). Oil degassing and gas expansion likely explain the abrupt oil-togas transition in the Alpine sandstone in northeastern NPRA. Evidence of oil saturation in Brookian stratigraphic plays west of the oil-to-gas transition suggests that Brookian strata may have been affected by these processes and may retain potential for undiscovered oil across northern NPRA (Housekneckt and others, 2010).

The Pioneer accumulation is mainly oil with little or no free gas, whereas the Spark-Rendezvous accumulation (see fig. 1 for well locations) is a much larger reservoir system that includes gas plus condensate at shallower depths in the north and oil at greater depths in the south. The Scout accumulation northwest of the Spark-Rendezvous accumulation is principally a gas accumulation.

Most known or inferred hydrocarbon accumulations west of Spark-Rendezvous are gas. This transition occurs just 15 to 20 miles west of the Alpine oil field and is not related to the structural position of the reservoir. Exceptions are the oil stained sands penetrated by the Kokoda 1 and Kokoda 5 wells.
It is assumed that these accumulations can be related to either the Kingak-Alpine petroleum system or to the GRZ/Pebble shale unit/Torok-Nanushuk petroleum system. Currently we have no evidence for biodegradation of petroleum and incorporation of methane from oil biodegradation into gas hydrate from the GRZ/Pebble shale unit/Torok-Nanushuk petroleum system.

Figure 11 shows the well chart from the Kokoda 5 well. A thick layer of potential gas hydrate is suggested between 1,220 to 1,450 ft. Elements learned from the Tarn 2N305 and Mount Elbert 1 wells can be applied here. The thick potential gas hydrate layer is coincidental with sustained increases in the diagnostic ratios $\left(\mathrm{C}_{1} / \mathrm{C}_{2}+\mathrm{C}_{3}, \mathrm{C}_{1} / \mathrm{CO}_{2}\right.$, and $\left.\mathrm{iC}_{4} / \mathrm{nC}_{4}\right)$ and accompanied by the isotopic filtration of methane $(-49 \%$ below to $-58 \%$ above the gas hydrate layer). The well chart for Kokoda 1 (appendix 4) shows similar characteristics to those of the nearby Kokoda 5 well. Other wells evaluated in this geologic setting are Noatak 1 and Caribou 26-11 (appendix 4).

Wells evaluated in the central and western NPRA are less well characterized and are assumed to be part of the GRZ/ Pebble shale unit/Torok-Nanushuk petroleum system, representing older, mature hydrocarbons. Of the three wells drilled in the central NPRA, only the Amaguq 2 well (appendix 4) shows promise for the presence of gas hydrate and concurrent thermogenic gas. The Aklaq 6 well is unique to the entire study in that there is no evidence for any part of a thermogenic gas source, yet limited geochemical evidence suggests the presence of potential gas hydrate at a depth of about $1,400 \mathrm{ft}$ (427 m) (appendix 4). Without well logs there is no way to verify this presence. The Aklaqyaq 1 well has limited potential for gas hydrate just above the base of gas hydrate stability and a potential coalbed just below $400 \mathrm{ft}(120 \mathrm{~m})$.

Wells in western NPRA drilled near the village of Wainwright for the purpose of evaluating the coalbed methane potential (Clark, 2010) penetrated more than 10 subbituminous coalbeds within the gas hydrate stability zone (appendix 4). Geochemical analyses used to prospect for gas hydrate can be mimicked by coalbed hydrocarbon gases; thus, addressing the know distribution of coal is an important consideration. Analysis of the data from both wells allows for some limited potential that gas hydrate may be associated with a series of thin $1-5 \mathrm{ft}(0.3$ to $1.6 \mathrm{~m})$ coalbeds within the depth interval of 900 to $1,000 \mathrm{ft}$ ( 290 to $328 \mathrm{~m}$ ). The potential production of coalbed methane from gas-hydrate-bearing coal may be less than expected because coal desorption tests that predict the amount of methane to be recovered are conducted in pressuretemperature conditions that allow for collecting the additional methane from the dissociation of gas hydrate. Under reservoir conditions, gas hydrate, if present, would not dissociate and may impede reservoir permeability by its presence in pore space.

\section{Models of Gas Hydrate Origin and Emplacement}

In the Prudhoe Bay region, it has been previously observed that gases from the Kuparuk River oil field may have 


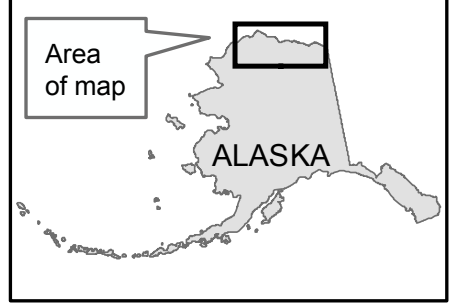

$160^{\circ} \mathrm{W}$

$155^{\circ} \mathrm{W}$

\begin{tabular}{|ccc|}
\hline \multicolumn{2}{|c|}{ EXPLANATION } \\
Gas hydrate & GHSZ thickness \\
Evidence & $3,800 \mathrm{ft}, 1,160 \mathrm{~m}$ \\
& Limited \\
& No evidence & 0 \\
\hline $50^{\circ} \mathrm{W}$ & \multicolumn{1}{|c|}{$145^{\circ} \mathrm{W}$} \\
\hline
\end{tabular}

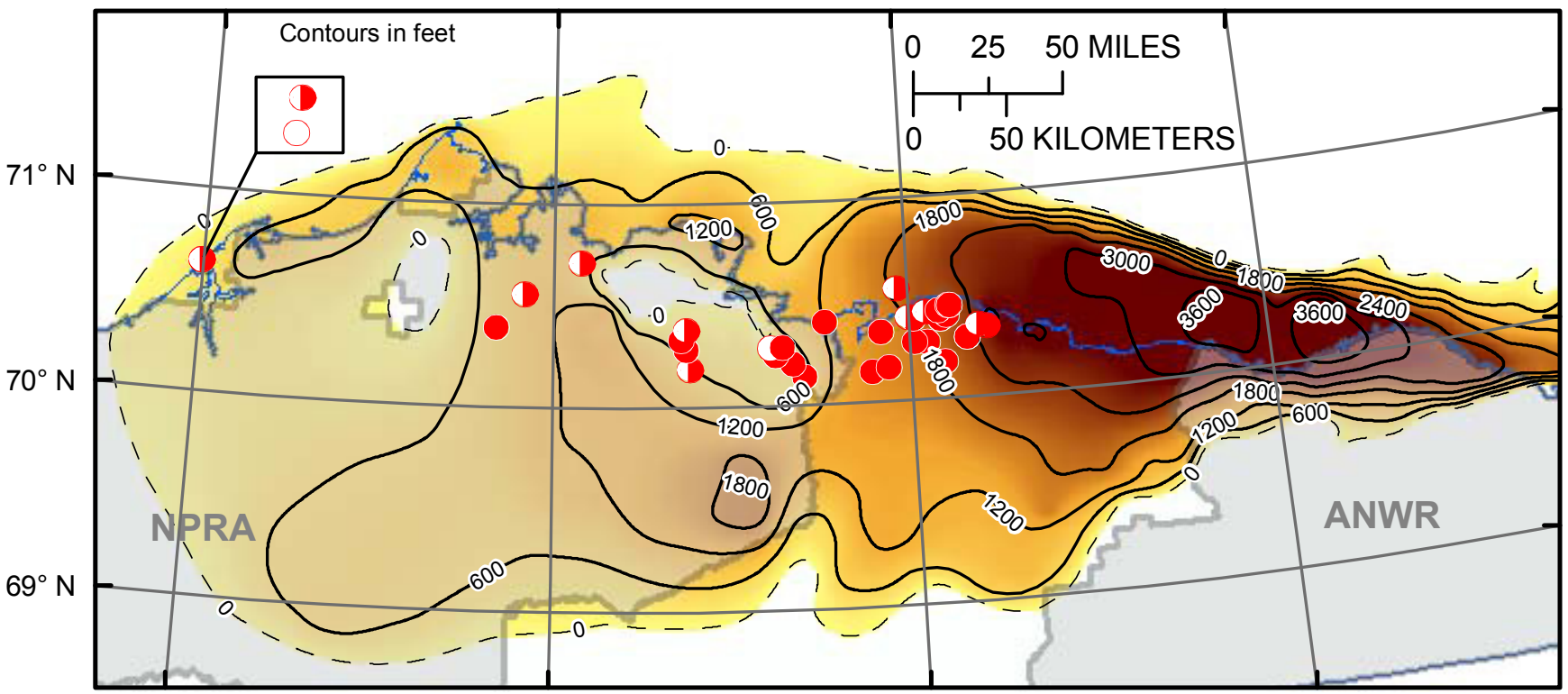

$160^{\circ} \mathrm{W}$

$155^{\circ} \mathrm{W}$

$150^{\circ} \mathrm{W}$

$145^{\circ} \mathrm{W}$

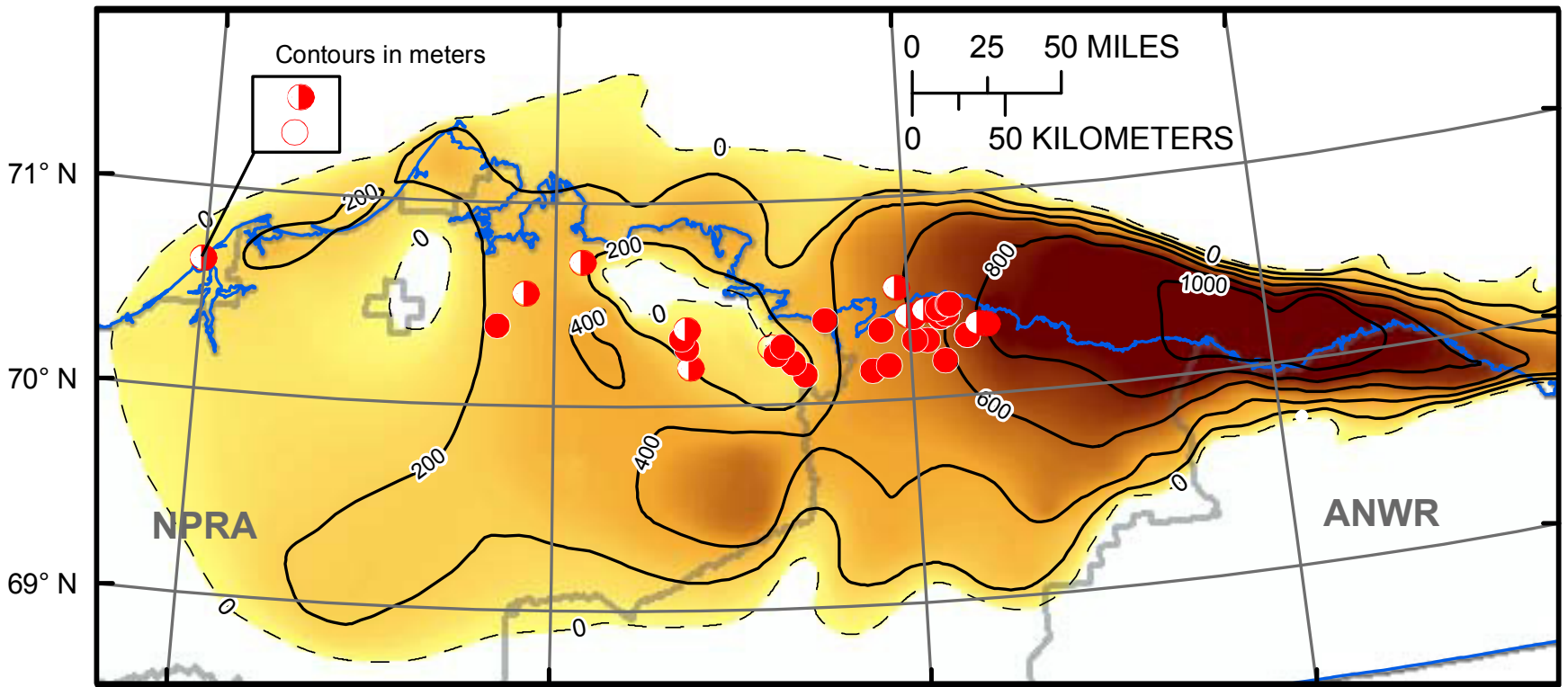

Alaska Albers, NAD83

Figure 8. Map showing the potential occurrence of gas hydrate on the North Slope of Alaska. The base map shows the estimated thickness of the gas hydrate stability zone on the North Slope based on data from selected oil and gas exploration wells and are compiled from geophysical logs of oil and gas wells, from down-hole temperature profiles or subsurface temperature of $0^{\circ} \mathrm{C}$ as measured in borehole temperature logs. Thermal data from Osterkamp and Payne (1981), Lachenbruch and others (1982, 1987), and Collett and others (1989). NPRA, National Petroleum Reserve in Alaska; ANWR, Arctic National Wildlife Refuge. Upper map shows the gas hydrate stability zone (GHSZ) thickness with contours in feet, and the lower map shows the gas hydrate stability zone thickness with contours in meters. 

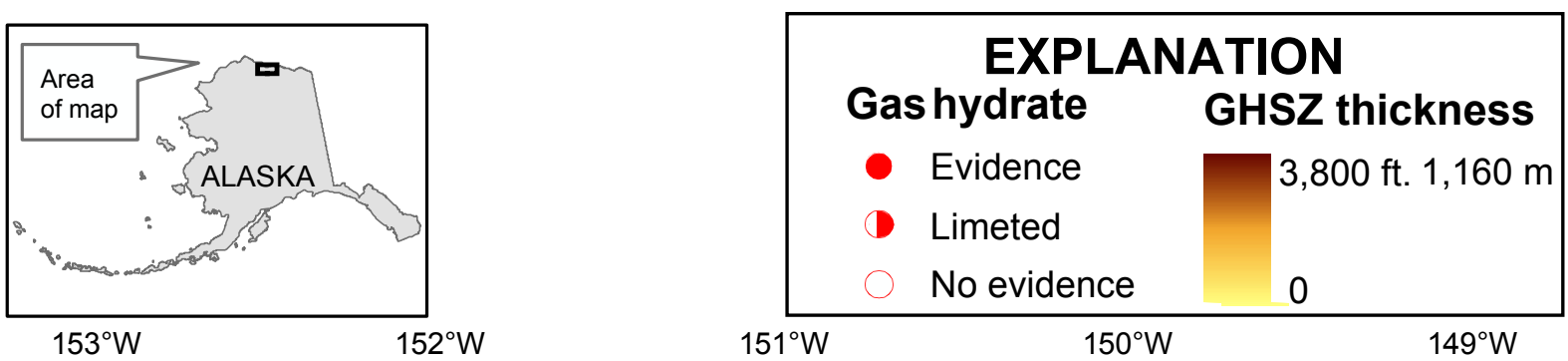

$151^{\circ} \mathrm{W}$

$150^{\circ} \mathrm{W}$

$149^{\circ} \mathrm{W}$

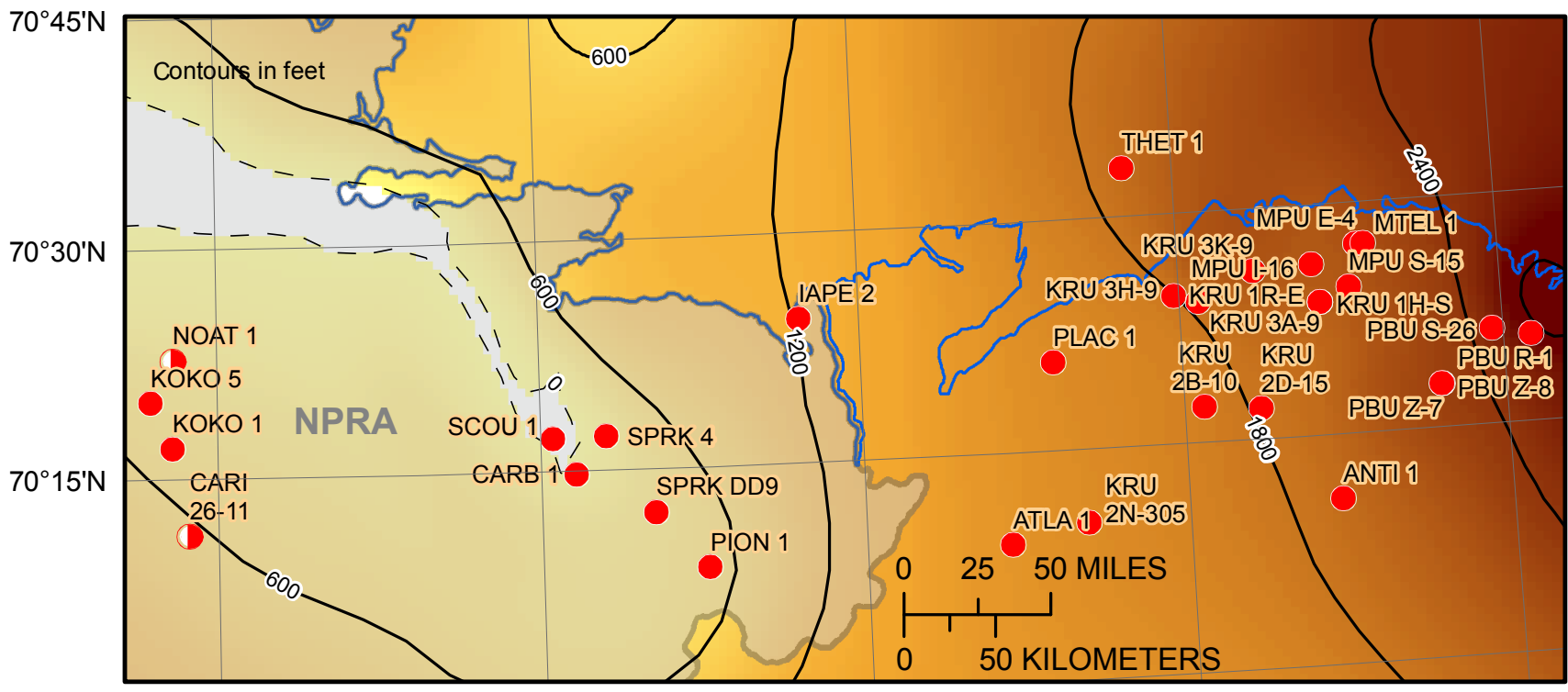

$153^{\circ} \mathrm{W}$

$152^{\circ} \mathrm{W}$

$151^{\circ} \mathrm{W}$

$150^{\circ} \mathrm{W}$

$149^{\circ} \mathrm{W}$

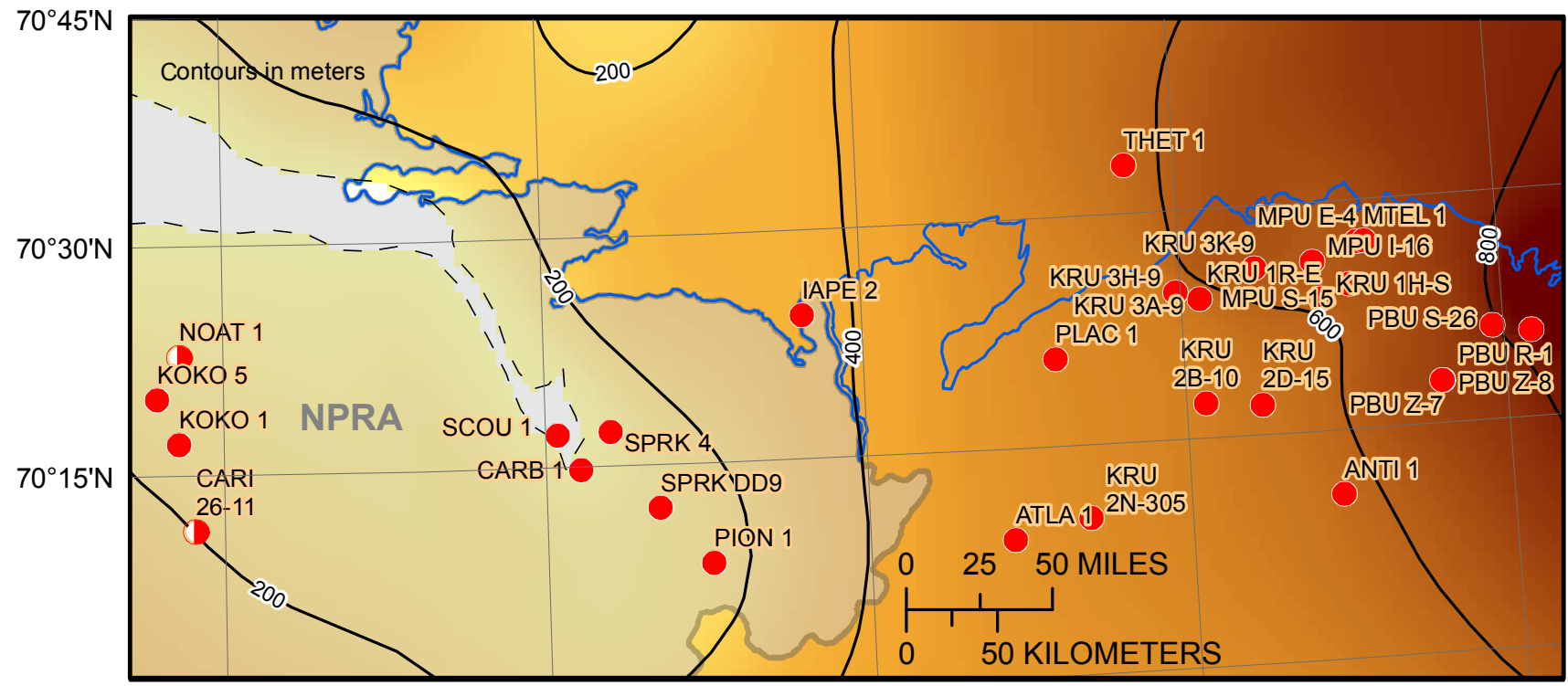

Alaska Albers, NAD83

Figure 9. Detailed map showing the potential occurrence of gas hydrate on the North Slope of Alaska. The base map shows the estimated thickness of the gas hydrate stability zone on the North Slope based on data from selected oil and gas exploration wells and are compiled from geophysical logs of oil and gas wells, from down-hole temperature profiles, or subsurface temperature of $0^{\circ} \mathrm{C}$ as measured in borehole temperature logs. Thermal data from Osterkamp and Payne (1981), Lachenbruch and others (1982, 1987), and Collett and others (1989). NPRA, National Petroleum Reserve in Alaska; ANWR, Arctic National Wildlife Refuge. Upper map shows the gas hydrate stability zone thickness with contours in feet, and the lower map shows the gas hydrate stability zone (GHSZ) thickness with contours in meters. For explanation of well name abbreviations see table 1. 

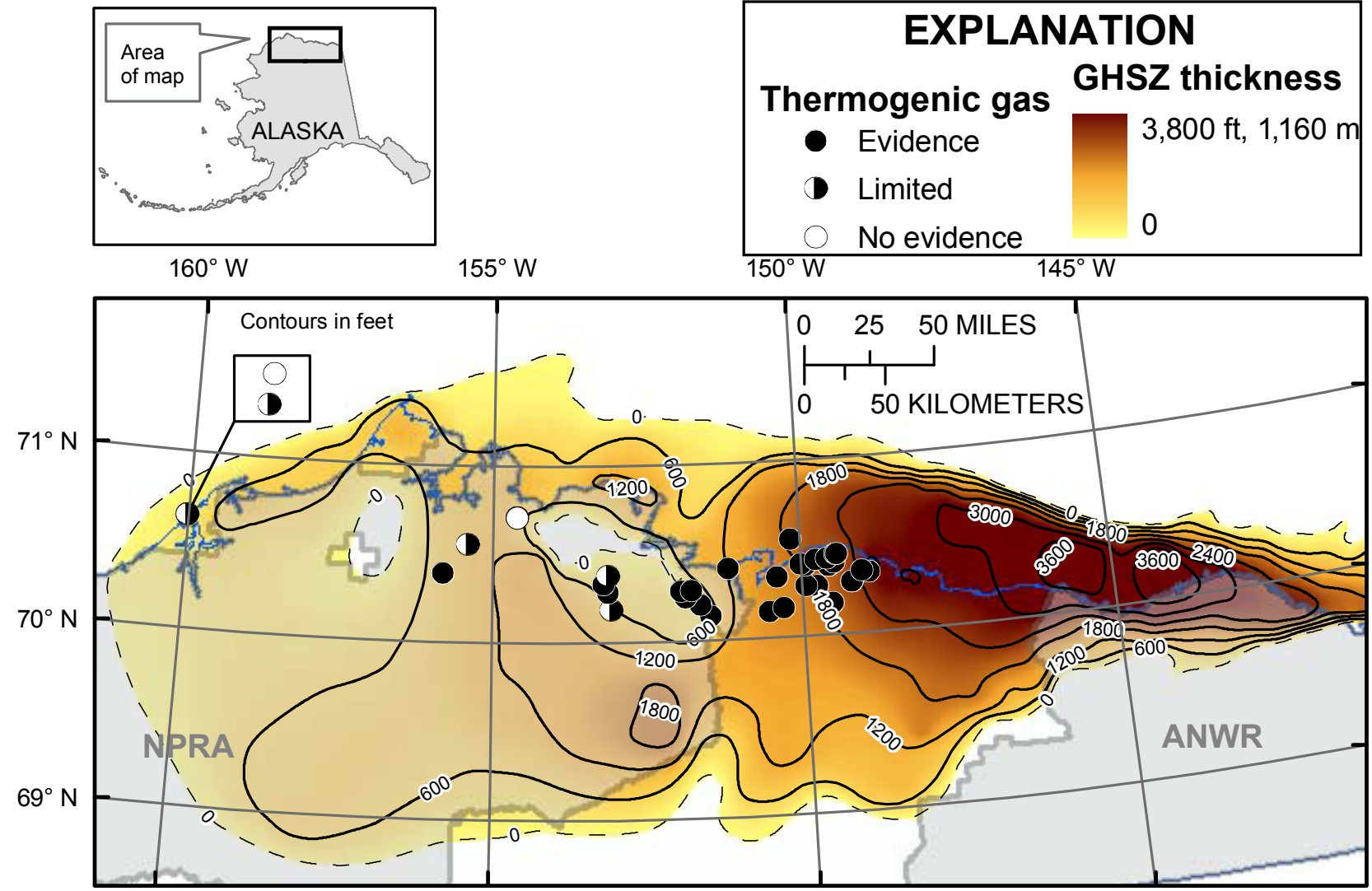

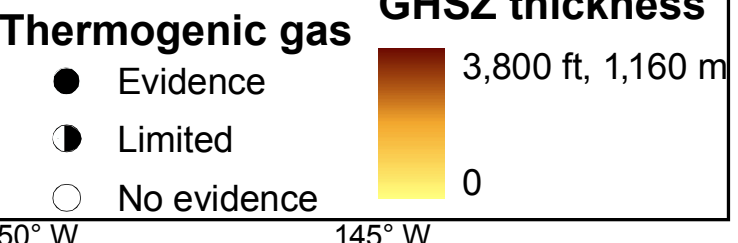

\section{EXPLANATION}

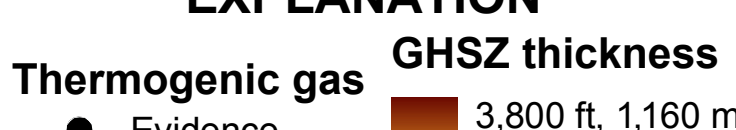
- Evidence

Limited $155^{\circ} \mathrm{W}$

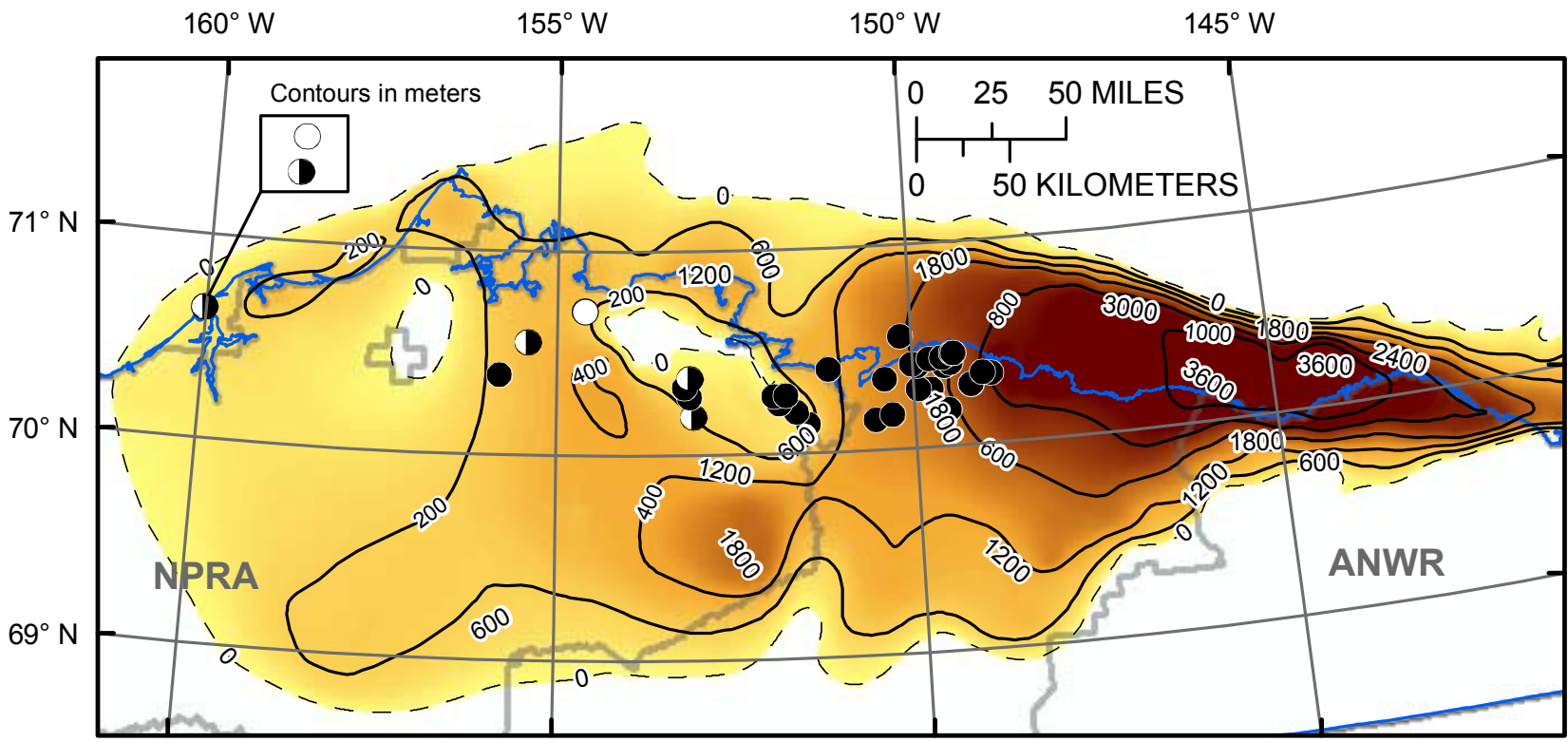

Alaska Albers, NAD83

Figure 10. Map showing evidence for thermogenic gas in wells on the North Slope of Alaska. The base map shows the estimated thickness of the gas hydrate stability zone on the North Slope based on data from selected oil and gas exploration wells and are compiled from geophysical logs of oil and gas wells, from down-hole temperature profiles, or subsurface temperature of $0^{\circ} \mathrm{C}$ as measured in borehole temperature logs. Thermal data from Osterkamp and Payne (1981), Lachenbruch and others (1982, 1987), and Collett and others (1989). NPRA, National Petroleum Reserve in Alaska; ANWR, Arctic National Wildlife Refuge. Upper map shows the gas hydrate stability zone (GHSZ) thickness with contours in feet, and the lower map shows the gas hydrate stability zone (GHSZ) thickness with contours in meters. 


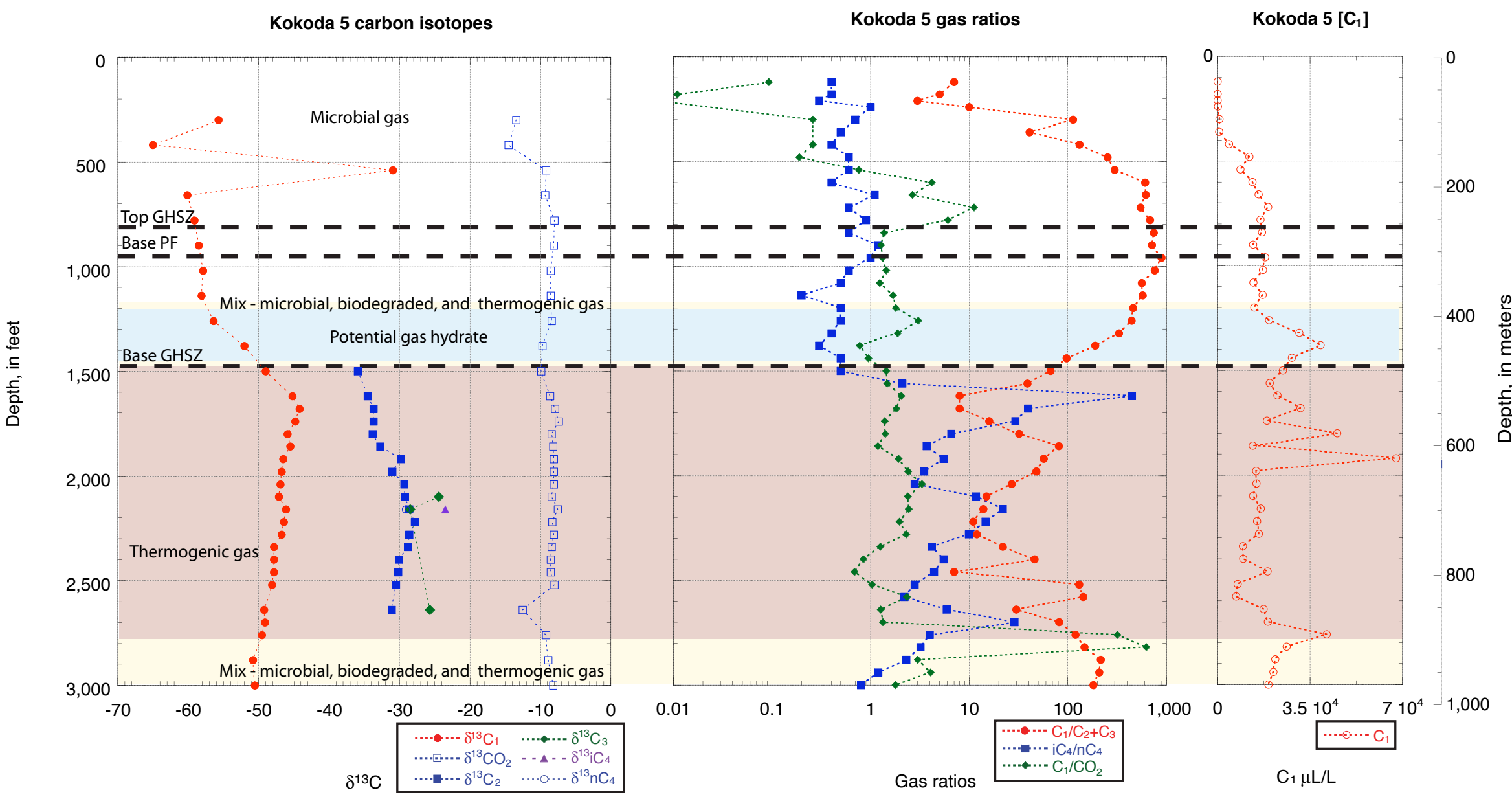

Figure 11. Geochemical data from the Kokoda 5 well (see fig. 1 for location). Parameters as described in text. Methane concentration units are given in the units of milliliters gas/ liters sediment (mL gas/L sediment). GHSZ, gas hydrate stability zone. 
leaked gas and condensate that subsequently followed fault conduits to oil and gas traps higher in the section (Masterson and others, 2001). This gas may have been trapped in the previously biodegraded oil of the West Sak field and recharged this field with lighter hydrocarbon components. We have added the gas hydrate occurrences to this model, illustrated in figure 12. Gas hydrate represents the up-dip "frozen" extension of gas from leaking oil fields. The ultimate source of gas is thermogenic but the gas has undergone modification mainly by biodegradation of some hydrocarbons and possibly by evaporative fractionation. The details and implications of this model can be found in Lorenson and others $(2009,2011)$.

Figure 13 depicts the proposed model for gas hydrate occurrences in NPRA. The concepts are similar to those presented in figure 12 - thermogenic gases migrate up zones of higher permeability with the addition of gas migration along clinoforms and into coalbeds as well as into sand reservoirs. Coalbeds can act as both a gas source and potential gas

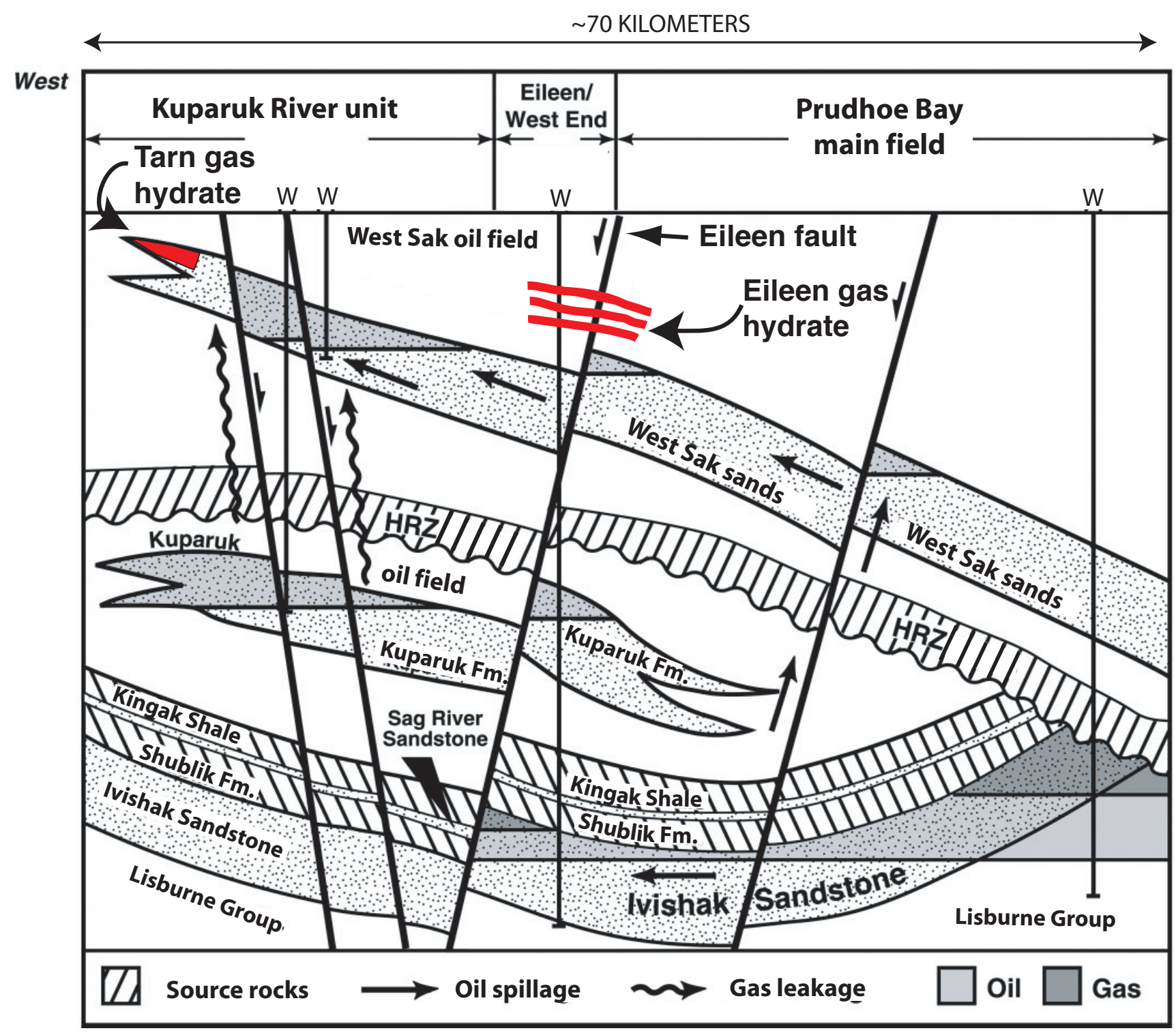

Figure 12. Stylized cartoon showing a schematic cross section of the Prudhoe-Kuparuk area (see fig. 5), showing possible gas sources, conduits, and traps, including the proposed filling history of the West Sak oil field (modified from Masterson and others, 2001). Gas hydrate occurrence has been schematically added to the model (shown in red) and reflects the relative position and origin of gas hydrate. Gas hydrate represents the up-dip extension of gas from leaking oil fields. The ultimate source of gas is thermogenic; however, the gas has undergone modification mainly by the anerobic biodegradation of oil resulting in the production of microbial methane. HRZ, highly radioactive zone of the Hue Shale. Ivishak Sandstone data from Jones and Speers (1976). W, well. 


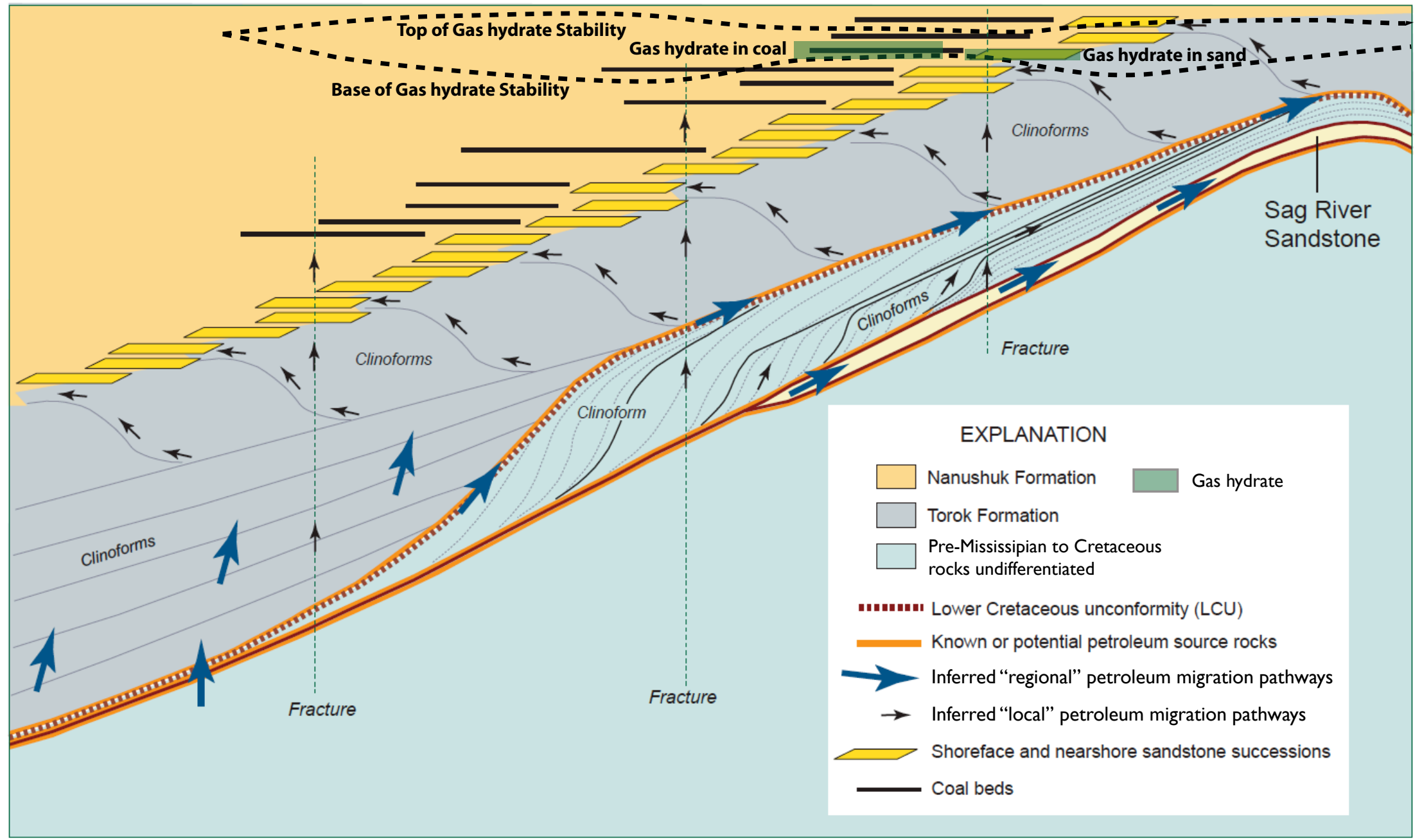

Figure 13. Generalized proposed model for gas hydrate occurrences in the National Petroleum Reserve in Alaska (NPRA). The concepts are similar to those shown in figure 12. Thermogenic gases migrate up zones of higher permeability with additional gas migration along clinoforms and into coalbeds as well as sand reservoirs. Coalbeds can act as both a gas source and potential gas reservoir for migrated hydrocarbons based on a model proposed by Houseknecht (2003) and Roberts (2008) for entrapment of petroleum in Brookian topset facies inclusive of the Nanushuk Formation. 
reservoir for migrated hydrocarbons based on a model proposed by Houseknecht (2003) and Roberts (2008) for entrapment of petroleum in Brookian topset facies inclusive of the Nanushuk Formation. Coalbeds as well as sandstones within these topset intervals would provide excellent reservoirs for the accumulation of gas migrating from deeper source rocks. Mechanisms for trapping could include a combination of stratigraphic and structural traps similar to models proposed by Lamarre (2003) for coalbed-gas fields in east-central Utah.

The most recent estimates of Alaska's gas hydrate resources of 85.4 TCF by the USGS (Collett and others, 2008) highlight the petroleum system approach to gas hydrate exploration models and assessments. It is evident that gas hydrate occurrences in northern Alaska, as well as other Arctic gas hydrate occurrences in Russia and Canada, are very closely related to underlying petroleum deposits; for example, the Messoyakha and Timan-Pechora basin (Yakushev and Chuvilin, 2000) and the Mackenzie Delta (Collett and Dallimore, 2000). Gas hydrate deposits are thus part of these petroleum systems that have been mainly ignored by the petroleum industry even though they occur in close association in stacked reservoir sections and would likely be produced together from the same wells and production facilities.

Analysis of the well-cutting data for wells in NPRA demonstrate a great likelihood of gas hydrate deposits in NPRA spread over a wide area. The potential conventional and coal gas sources in NPRA underlying gas hydrate deposits are substantial and have likely contributed hydrocarbon gas to the overlying gas hydrate. The most recent gas assessment in NPRA by Housekneckt and others (2010) estimates a mean total of $61.3 \mathrm{TCF}$, whereas the mean quantity of coalbed methane is estimated to be 18.1 TCF (Roberts, 2008). Less important gas sources may be deeply buried organic-rich sediments that can produce enough microbial methane to seed gas hydrate crystallization (Aklaq 2 example, appendix 4).

Arctic gas hydrate deposits also serve as traps collecting methane that would otherwise be emitted to the overburden and potentially reach the atmosphere. Methane is a very potent greenhouse gas and is currently the object of much concern in climate change science. Masterson (2001) estimated that only about 20 percent of the Prudhoe Bay gas cap has been retained and that about 17 percent of the original gas charge has been incorporated into the overlying gas hydrate deposits. Over geologic time periods, gas hydrates are important sequesters of methane in the Arctic.

\section{Conclusions}

As part of a USGS and BLM collaboration, drilling mud gases and gases from well cuttings have been collected and analyzed from industry-drilled wells on the Alaska North Slope. Recently, this analysis has also included NPRA for the purpose of prospecting for gas hydrate deposits. Since 1979, 35 wells have been sampled from as far west as Wainwright to Prudhoe Bay in the east. Regionally, the USGS has assessed the gas hydrate resources of the North Slope and determined that there is about $85.4 \mathrm{TCF}$ of technically recoverable hydrate-bound gas within 3 petroleum systems. The systems are mainly defined by 3 separate stratigraphic intervals and constrained by the physical temperatures and pressures where gas hydrate can form. Geochemical studies of known gas hydrate occurrences on the North Slope have shown a link between gas hydrate and more deeply buried conventional oil and gas deposits. The link is established when hydrocarbon gases migrate from depth and charge the reservoir rock within the gas hydrate stability zone. Gases likely migrated into conventional traps as free gas and were later converted to gas hydrate in response to climate cooling concurrent with permafrost formation.

Gas hydrate and permafrost are partial barriers to gas migration and enhance isotopic partitioning of hydrocarbon gases. The ratios $\mathrm{C}_{1} / \mathrm{C}_{2}+\mathrm{C}_{3}, \mathrm{C}_{1} / \mathrm{CO}_{2}$, and $\mathrm{iC}_{4} / \mathrm{nC}_{4}$ along with $\mathrm{C}_{1}$ concentrations and hydrocarbon isotopic composition can help infer the potential occurrence of gas hydrates.

Gas hydrate has been cored and recovered in the Mount Elbert 1 well, providing a model for predicting gas hydrate occurrences elsewhere. Results from this study indicate that gas hydrate is likely present in 23 wells on the basis of gas geochemistry, inferred by equivocal gas geochemistry in 11 wells, and is not present in 1 well. Some contribution from thermogenic gas is present in 29 of the wells, with limited evidence in 4 wells and only 2 wells without thermogenic gas. Coalbeds are widespread and may contribute to gas hydrate formation. Gas migration routes are common in the North Slope and include faults and widespread, continuous, shallowly dipping delta sands that are potentially in contact with deeper oil and gas sources. The application of this model with the geochemical evidence suggests that gas hydrate deposits may be widespread across the North Slope of Alaska.

\section{Acknowledgments}

We thank Arco Alaska, BP Exploration Alaska, Conoco Phillips, Exxon, FEX LP, Standard Oil of Ohio, and the USGS Alaska coalbed methane project for access to data, resources, and drilling knowledge and to all the people who have participated in the field collection of samples. We thank the drillers and staff at the well sites for their efforts in obtaining samples and providing logistical support during the field program. Florence Wong and Margo Zyrianova of the USGS contributed much to the GIS support and map figures in this report. The manuscript benefited from a thorough edit by Jim Hendley and helpful reviews by Bob Rosenbauer and Burt Thomas of the USGS.

\section{References Cited}

Alexander, R., Kagi, R.I., and Woodhouse, G.W., 1983, Variation in the ratio of isomeric butanes with sediment 
temperature in the Carnarvon basin of western Australia, in Advances in Organic Geochemistry, 1981: Proceedings of the International Meeting on Organic Geochemistry, v. 10, p. 76-79.

Bernard, B.B., Brooks, J.M., and Sackett, W.M., 1978, Light hydrocarbons in recent Texas continental shelf and slope sediments: Journal of Geophysical Research, v. 83, p. 4053-4061.

Berner, U., and Bertrand, P., 1991, Light hydrocarbons in sediments of the Sulu Sea Basin (Site 768): genetic characterization by molecular and stable isotope composition: College Station, Texas, Ocean Drilling Program, Proceedings Ocean Drilling Program, Scientific Results, v. 124, p. 227-231.

Bird, K.J., 2001, Alaska; a twenty-first-century petroleum province, in Downey, M.W., Threet, J.C., and Morgan, W.A., eds., Petroleum provinces of the twenty-first century: American Association of Petroleum Geologists Memoir 74, p. 137-165.

Boswell R., Rose, K., Collett, T.S., Lee M., Winters, W., Lewis, K.A., and Agena, W., 2011, Geologic controls on gas hydrate occurrence in the Mount Elbert prospect, Alaska North Slope: Marine and Petroleum Geology, v. 86, p. 589-607.

Burruss, R.C., Lillis, P.G., and Collett, T.S., 2003, Geochemistry of natural gas, North Slope, Alaska - implications for gas resources, NPRA: U.S. Geological Survey Open-File Report 03-329, available at http://pubs.usgs.gov/of/2003/ of03-041/text.htm.

Clark, A.C., Roberts, S.B., and Warwick, P.D., 2010, Geologic cross section, gas desorption, and other data from four wells drilled for Alaska Rural Energy Project, Wainwright, Alaska, coalbed methane project, 2007-2009: U.S. Geological Survey Open-File Report 2010-1210, 1 p., available at http://pubs.usgs.gov/of/2010/1210/.

Collett, T.S., 1993, Natural gas hydrates of the Prudhoe Bay and Kuparuk River area, North Slope Alaska: American Association of Petroleum Geologists Bulletin, v. 77, no. 5, p. 793-812.

Collett, T.S., 1997, Gas hydrate resources of northern Alaska: Bulletin of Canadian Petroleum Geology, v. 45, no. 3, p. 317-338.

Collett, T.S., 2002, Energy resource potential of natural gas hydrates; unconventional petroleum systems: American Association of Petroleum Geologists Bulletin, v. 86, no. 11, p. 1971-1992.

Collett, T.S., Agena, W.F., Lee, M.W., Zyrianova, M.V., Bird, K.J., Charpentier, R.R., Cook, T., Houseknecht, D.W., Klett, T.R., Pollastro, R.M., and Schenk, J.S., 2008, Assessment of gas hydrate resources on the North Slope, Alaska, 2008: U.S. Geological Survey Fact Sheet 2008-3073, 4 p., available at http://pubs.usgs.gov/fs/2008/3073/.

Collett, T.S., Bird, K.J., Kvenvolden, K.A., and Magoon, L.B., 1989, Map showing the depth to the deepest ice-bearing permafrost as determined from well logs, North Slope, Alaska: U.S. Geological Survey Oil and Gas Investigations Map 222, 1 plate, 15 p., scale 1:1,000,000.

Collett, T.S., and Dallimore, S.R., 2000, Permafrost-associ ated gas hydrate, in Max, M.D., ed., Coastal systems and continental margins 5; natural gas hydrate in oceanic and permafrost environments: Dordrecht, Netherlands, Kluwer Academic Publishers, p. 43-60.

Collett, T.S., Johnson, A.H., Knapp, C.C., and Boswell, R., 2009, Natural gas hydrates - a review, in Collett, T.S., Johnson, A.H., Knapp, C.C., and Boswell, R., eds., Natural gas hydrates - energy resource potential and associated geologic hazards: American Association of Petroleum Geologists Memoir 89, p. 146-219.

Collins, F.R., 1958, Test wells, Meade and Kaolak areas, Alaska, with micropaleontology of Meade test well 1 and Kaolak test well 1, northern Alaska, by H.R. Bergquist: U.S. Geological Survey Professional Paper 303-F, p. 341-376.

Faber, E., and Stahl, W., 1983, Analytic procedure and results of an isotopic geochemical surface survey in an area of the British North Sea, in Brooks, James, ed., Petroleum geochemistry and exploration of Europe: London, Blackwell Publishing, p. 51-63.

Head, I.M., Jones, D.M., and Larter, S.R., 2003. Biological activity in the deep subsurface and the origin of heavy oil: Nature, v. 42, p. 344-352.

Houseknecht, D.W., 2003, Brookian stratigraphic plays in the National Petroleum Reserve-Alaska (NPRA): U.S. Geological Survey Open-File Report 03-039, available at http://pubs.usgs.gov/of/2003/of03-039/.

Houseknecht, D.W., Bird, K.J., Schuenemeyer, J.H., Attanasi, E.D., Garrity, C.P., Schenk, C.J., Charpentier, R.R., Pollastro, R.M., Cook, T.A., and Klett, T.R., 2010, 2010 updated assessment of undiscovered oil and gas resources of the National Petroleum Reserve in Alaska (NPRA): U.S. Geological Survey Fact Sheet 2010-3102, 4 p., available at http://pubs.usgs.gov/fs/2010/3102/.

Lachenbruch, A.H., Sass, J.H., Lawver, L.A., Brewer, M.C., Marshall, B.V., Munroe, R.J., Kennelly, J.P., Jr., Galanis, S.P., Jr., and Moses, T.H., Jr., 1987, Temperature and depth of permafrost on the Alaskan North Slope, in Tailleur, I.L., and Weimer, Paul, eds., Alaskan North Slope geology: Bakersfield, Pacific Section, Society of Economic Paleontologists and Mineralogists Book No. 50, p. 545-558.

Lachenbruch, A.H., Sass, J.H., Marshall, B.V., and Moses, T.H., Jr., 1982, Permafrost heat flow and the geothermal regime at Prudhoe Bay, Alaska: Journal of Geophysical Research, v. 87, no. B11, p. 9301-9316.

Lamarre, R.A., 2003, Hydrodynamic and stratigraphic controls for a large coalbed methane accumulation in Ferron coals of east-central Utah, in Collett, T.S., and Barker, C.E., eds., Coalbed methane in the Ferron coals, Utah: International Journal of Coal Geology, v. 56, issues 1-2, p. 97-110.

Lorenson T.D., Collett, T.S., and Hunter, R.B., 2011, Gas geochemistry of the Mount Elbert Gas Hydrate Stratigraphic Test Well, Alaska North Slope_-implications for gas hydrate exploration in the Arctic: Marine and Petroleum Geology, v. 86, p. 343-360.

Lorenson, T.D., Collett, T.S., and Whiticar, M.J., 2009, Hydrocarbon gas composition and origin of gas hydrate from the 
Alaska North Slope, in Collett, T.S., Johnson, A.H., Knapp, C.C., and Boswell, R., eds., Natural gas hydrates-energy resource potential and associated geologic hazards: American Association of Petroleum Geologists Memoir 89, p. 584-597.

Lorenson, T.D., Whiticar, M.J., Collett. T.S., Dallimore, S.R., and Dougherty, J.A., 2005, Complete gas composition and isotopic geochemistry from the JAPEX/JNOC/ GSC et al. Mallik 5L-38 gas hydrate production research well - cuttings, core, gas hydrate, and production testing results, in Dallimore, S.R., and Collett, T.S., eds., Scientific results from Mallik Gas Hydrate Production Research Well Program, Mackenzie Delta, Northwest Territories, Canada: Geological Survey of Canada Bulletin 585, p. 94, 19 p. [CD-ROM].

Lorenson, T.D., Whiticar, M.J., Waseda, A, Dallimore, S.R., and Collett, T.S., 1999, Gas composition and isotopic geochemistry of cuttings, core, and gas hydrate from the JAPEX/JNOC/GSC Mallik 2L-38 gas hydrate research well, in Dallimore, S.R., and Collett, T.S., eds., Scientific results from JAPEX/JNOC/GSC Mallik 2L-38 gas hydrate research well, Mackenzie Delta, Northwest Territories, Canada: Geological Survey of Canada Bulletin 544, p. 143-163.

Magoon, L.B., and Dow, W.G., 1994, The petroleum system, in Magoon, L.B., and Dow, W.G., eds., The petroleum system - from source to trap: American Association of Petroleum Geologists Memoir 60, p. 3-24.

Magoon, L.B., Lillis, P.G., Bird, K.J., Lampe, C., and Peters, K.E., 2003, Alaskan North Slope petroleum systems: U. S. Geological Survey Open-File Report 03-324, 3 sheets, available at http://pubs.usgs.gov/of/2003/of03-324/.

Masterson, W.D., Dzou, L.I.P., Holba, A.G., Fincannon, A.L., and Ellis, L., 2001, Evidence for biodegradation and evaporative fractionation in West Sak, Kuparuk, and Prudhoe Bay field areas, North Slope, Alaska: Organic Geochemistry, v. 32, no. 3, p. 411-441.

Molenaar, C.M., Bird, K.J., and Collett, T.S., 1986. Regional correlation sections across the North Slope of
Alaska: U. S. Geological Survey Miscellaneous Field Studies Map 1907, 1 sheet.

Mull, C.G, Housenecht, D.W., and Bird, K.J., 2003.

Revised Cretaceous and Tertiary stratigraphic nomenclature in the Colville Basin, northern Alaska: U. S. Geological Survey Professional Paper 1673, available at http://pubs.usgs.gov/pp/p1673/.

Osterkamp, T.E., and Payne, M.W., 1981, Estimates of permafrost thickness from well logs in northern Alaska: Cold Regions Science And Technology, v. 5, p. 13-27.

Roberts, S.B., compiler, 2008, Geologic assessment of undiscovered, technically recoverable coalbed-gas resources in Cretaceous and Tertiary rocks, North Slope and adjacent State waters, Alaska: U.S. Geological Survey Digital Data Series DDS-69-S, 4 chapters [CD-ROM], available at http://pubs.usgs.gov/dds/dds-069/dds-069-s/.

Tyler, R., Scott, A.R., and Clough, J.G., 2000, Coalbed methane potential and exploration targets for rural Alaskan communities: Alaska Division of Geological and Geophysical Surveys Preliminary Interpretive Report 2000-2, 177 p.

Werner, M.R., 1987, West Sak and Ugnu sands-low-gravity oil zones of the Kuparuk River area, Alaskan North Slope, in Tailleur, I., and Weimer, P., eds., Alaskan North Slope Geology: Pacific Section, Society of Economic Paleontologists and Mineralogists and the Alaska Geological Society, 50, p. 109-118.

Whiticar, M.J., Faber, E., and Schoell, M., 1986. Biogenic methane formation in marine and freshwater environments - $\mathrm{CO} 2$ reduction versus acetate fermentation: isotopic evidence: Geochimica Cosmochimica Acta, v. 50, p. 693-709.

Valin, Z.C., and Collett, T.S., 1992, Molecular and isotopic analysis of the hydrocarbon gases within gas hydrate-bearing rock units of the Prudhoe Bay Kuparuk River area in northern Alaska: U.S. Geological Survey Open-File Report 92-299, $90 \mathrm{p}$.

Yakushev, Y.S., and Chuvilin, E.M., 2000, Natural gas and gas hydrate accumulations within permafrost in Russia: Cold Regions Science and Technology, v. 31, p. 189-197. 


\section{Appendix 1. Analytical Laboratories and Methods Used During Stage One of the North Slope, Alaska, Gas Hydrate Study, 1983-1991}

Two USGS laboratories (Branch of Petroleum Geology laboratories, Denver, Colorado, and Branch of Pacific Marine Geology laboratories, Palo Alto, California) and two contract laboratories (Geochem Research Incorporated, Houston, Texas, and Global Geochemistry Corporation, Canoga Park, California) were used to analyze the samples collected from the 10 wells in this study. Cooperative research efforts also permitted the West German Federal Institute for Geosciences and Natural Resources (BGR) to analyze samples from the Kuparuk River Unit 2B-10 and Kuparuk River Unit 2D-15 wells. A description of the analytical methods used in each of these laboratories follows.

\section{USGS Branch of Petroleum Geology}

At the USGS Branch of Petroleum Geology laboratory the canned drill cuttings were permitted to outgas for several weeks before analyzing the headspace gas. The cans were punctured, internal pressures were measured, and a sample of gas was acquired. The headspace gas sample was injected into a gas chromatograph and the components air, carbon dioxide $\left(\mathrm{CO}_{2}\right)$, methane $\left(\mathrm{C}_{1}\right)$, ethane $\left(\mathrm{C}_{2}\right)$, and propane $\left(\mathrm{C}_{3}\right)$ through normal-pentane $\left(n \mathrm{C}_{5}\right)$ were separated and identified with a thermal conductivity detector. During the chromatographic separation, the methane peak was diverted into a syringe for injection and subsequent oxidation to $\mathrm{CO}_{2}$ in a Leco induction furnace. The oxidized methane was dehydrated and the stable $\mathrm{C}$ isotopic composition of methane was measured on a NierMcKinney mass spectrometer and reported in the delta notation relative to the Peedee belemnite (PDB) marine carbonate standard (C.N. Threlkeld, USGS, written commun., 1987,). The bottled free gas samples were analyzed in the same manner as the canned headspace samples.

\section{USGS Branch of Pacific Marine Geology}

The canned drill cuttings analyzed at the USGS Branch of Pacific Marine Geology laboratory were equipped with septa covered ports. Before analysis, the can was shaken for 10 minutes. A 8-mL aliquot of helium was injected into the can and an equal amount of headspace gas was withdrawn and analyzed. The gas analysis was performed on a Karl model 311 gas chromatograph equipped with flame ionization and thermal conductivity detectors. The gas chromatograph was calibrated with standard mixtures of hydrocarbon gases, $\mathrm{CO}_{2}$, and air. Calculations of gas concentrations were made by integrating the areas of the chromatograph peaks and comparing the values with the standards. The bottled free gas samples and a limited number of vacuum tube-stored samples were analyzed in a manner similar to the analyses of the canned headspace samples.

\section{Geochem Research Incorporated}

At the Geochem Research Incorporated laboratory, a silicone rubber septum was attached to the lid of the canned sample in preparation for the $\mathrm{C}_{1}-\mathrm{C}_{7}$ headspace gas analysis. Before analysis, the can was shaken by hand for 1 minute. A small hole was pierced through the septum, and a sample of gas was withdrawn with a $2-\mathrm{mL}$ syringe after a positive pressure (one atmosphere) was created in the can by the injection of $2 \mathrm{~mL}$ of degassed water. The $2-\mathrm{mL}$ headspace gas sample was injected into a standard 1-mL gas sample loop attached to a Varian Aerograph 1400 isothermal gas chromatograph, equipped with a $3.18 \mathrm{~mm}$ by $2.44 \mathrm{~m}$ alumina-packed column and a flame ionization detector. This column resolves $\mathrm{C}_{1}$, $\mathrm{C}_{2}, \mathrm{C}_{3}$, isobutane and normal butane and, if present, the $\mathrm{C}_{2}$, $\mathrm{C}_{3}$, and $\mathrm{C}_{4}$ olefinic hydrocarbons. After the normal butane peak eluted, the flow of carrier gas through the system was reversed with a back-flush valve, and the $\mathrm{C}_{5}-\mathrm{C}_{7}$ hydrocarbons were eluted as a single composite chromatographic peak. The concentration of each hydrocarbon was computed from the peak area by means of an electronic integrator with baseline correction. Before a suite of samples were analyzed, a light-gas standard containing $100 \mathrm{ppm}$ each of methane, ethane, propane, isobutane, and normal butane were analyzed in triplicate. Analytical reproducibility is consistently within 2-3 percent of the observed value.

After the can was opened, an aliquot of 10-mL of wet cuttings was placed in a specially designed, sealed blender for the $\mathrm{C}_{1}-\mathrm{C}_{7}$ cuttings gas analysis. The sample was disaggregated for 2-3 minutes. A 2-mL sample of degassed water was injected into the $10-\mathrm{mL}$ air space at the top of the blender, and an equal amount of headspace gas was withdrawn. This $2-\mathrm{mL}$ gas sample was analyzed in the same manner as the canned headspace gas.

\section{Global Geochemistry Corporation}

At Global Geochemistry Corporation laboratory, the $\mathrm{C}_{1}-\mathrm{C}_{5}$ hydrocarbon composition of the canned headspace gases and free gas samples were measured on a Hach 400 gas chromatograph equipped with a sample/back-flush valve, two $3.18 \mathrm{~mm}$ by $2.44 \mathrm{~m}$ stainless steel columns in a series/ 
bypass configuration, and a flame ionizer detector. Analyses were completed in 15 minutes employing an He carrier gas $\left(30 \mathrm{~mL} / \mathrm{min}\right.$ ) and an oven temperature of $60^{\circ} \mathrm{C}$. As the individual hydrocarbon components eluted they were channeled to a vacuum line for isotopic analyses. The hydrocarbons were combusted to $\mathrm{CO}_{2}$ and $\mathrm{H}_{2} \mathrm{O}$ in a cupric furnace (held at $800^{\circ} \mathrm{C}$ ). The $\mathrm{CO}_{2}$ was collected at the sample tube, and the $\mathrm{H}_{2} \mathrm{O}$ was collected in a separate sample tube containing precombusted zinc reagent. The zinc tube was heated at $500^{\circ} \mathrm{C}$ for one hour to convert the $\mathrm{H}_{2} \mathrm{O}$ to $\mathrm{H}_{2}$ gas. Carbon $\left(\delta^{13} \mathrm{C}\right)$ and deuterium $(\delta \mathrm{D})$ isotopic measurements were made on a Nuclide $\left(7.62 \mathrm{~cm}, 60^{\circ} \mathrm{C}\right)$ dual-collecting stable isotopic ratio mass spectrometer and were reported relative to the Peedee belemnite (PDB) marine carbonate standard and the Standard Mean Oceanic Water (SMOW) international standard, respectively. Analytical reproducibility is typically $\pm 0.2 \%$ for carbon and $\pm 3 \%$ o for hydrogen. The gas chromatograph was calibrated with in-house gas standards.

\section{West German Federal Institute for Geosciences and Natural Resources (BGR)}

See Faber and Stahl (1983) for an analytical description of the laboratory methods employed at theWest German Federal Institute for Geosciences and Natural Resources.

\section{Appendix 2. Tables of Previously Published Gas Geochemistry for North Slope, Alaska, Wells Drilled from 1979 to 1991}

[Samples are reported in parts per million ( $\mathrm{ppm})$ in headspace or free gas. HS, freegas headspace; BHA, well-cutting headspace gas]

(See linked workbook files.)

\section{Appendix 3. Tables of Gas Geochemistry for North Slope, Alaska, Wells Drilled from 1993 to 2009}

[Results are reported in micro liters gas per liter $(\mathrm{mL} / \mathrm{L})$ of well cuttings and as parts per million (ppm) for free gas]

(See linked workbook files.)

\section{Appendix 4. Charts of Well-Cuttings Geochemistry and Interpretation for North Slope, Alaska, Wells Analyzed in this Report}

[Interpretations include geochemical summaries with selected geologic horizions for the wells evaulated in this report. Marked horzions are: top of the gas hydrate stabilitiy zone, (top GHSZ); base of the gas hydrate stabilitiy zone, (base GHSZ); base of ice-bearing permafrost (base PF). Criteria for defining gas sources and likely accumulations of gas hydrate are given in the text] (See linked file.) 

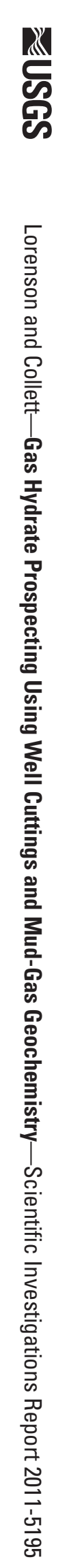